Z. Dt. Ges. Geowiss. (German J. Geol.), 170 (2), p. 161-180, 7 figs., 3 tables

\title{
The new critical metals database "HTMET": High tech trace element characteristics of sulphides from base metal provinces in the Variscan basement and adjacent sedimentary rocks in Germany
}

\author{
Sören Henning ${ }^{1,3}$, Sven Birkenfeld ${ }^{2}$, Torsten Graupner ${ }^{1}$, Henrike Franke ${ }^{1,2}$, Bernd Nawothnig ${ }^{2}$ \\ \& Katja Pursche ${ }^{1 *}$
}

Henning, S., Birkenfeld, S., Graupner, T., Franke, H., Nawothnig, B. \& Pursche, K. (2019): The new critical metals database "HTMET": High tech trace element characteristics of sulphides from base metal provinces in the Variscan basement and adjacent sedimentary rocks in Germany. - Z. Dt. Ges. Geowiss., 170: 161-180, Stuttgart.

\begin{abstract}
High tech (HT) trace elements such as germanium, gallium and indium gain rising importance in the development of innovative technologies. The database "HTMET" forms the first nationwide metal-ore database for Germany, created to visualise HT metal characteristics of base metal ores from important mining districts. Mineralogical and geochemical investigations on 478 samples and ore concentrates from $109 \mathrm{~Pb}-\mathrm{Zn}-\mathrm{Cu}$ occurrences were carried out using analytical methods with high spatial resolution and bulk sample methods. The database provides aggregated data based on 17,000 geochemical data sets, compiled information on regional infrastructure and environmental risks as well as data on innovative raw material-efficient processing techniques. Evaluation of combined data provides interactive maps revealing new potentials for specific HT metals in Germany.

Differences in regional distribution of these trace elements and dependency of their concentration levels in the ore on the genetic deposit type became apparent. Sphalerite from the sediment-hosted massive sulphide (SHMS) deposit "Rammelsberg" and skarn deposits in the Erzgebirge contain elevated indium contents (median 14-119 ppm), whereas the SHMS deposit "Meggen" is poor in HT metals. Germanium forms the predominant HT trace element in colloform sphalerite of Mississippi-Valley-Type (MVT) deposits (median 29-147 ppm); in contrast, crystalline sphalerite is low in germanium in this deposit type. Sphalerite in all hydrothermal vein deposits shares a distinct enrichment in gallium (median 6-81 ppm); however, germanium and indium concentrations vary significantly depending on the metal source and fluid conditions. The Ruhrgebiet and the Schwarzwald ore veins show an enrichment in germanium (median 55-73 ppm), whilst vein sphalerite from the Erzgebirge is specialised in indium (median $33 \mathrm{ppm}$ ). The data demonstrate that the HT trace element inventory of the studied base metal sulphides is not only a function of the genetic ore deposit type, but is also triggered by locally variable geology such as source rock and fluid composition and organic content of the rock. Gallium seems to derive from adjacent lithologies, whereas indium and germanium may have more distant sources.
\end{abstract}

Kurzfassung: Durch die fortschreitende Verbreitung und Weiterentwicklung von modernen Technologien erlangen die sogenannten hochtechnologierelevanten (HT) Spurenelemente Germanium, Gallium und Indium steigende Bedeutung. Die „HTMET“-Datenbank ist das erste deutschlandweite Metallerz-Kataster, welches die HT-Metall-,,Spezialisierung“ wichtiger Buntmetall-Bergbaudistrikte reflektiert. An 478 Erzproben und -konzentraten aus $109 \mathrm{~Pb}-\mathrm{Zn}-\mathrm{Cu}$-Vorkommen wurden mittels hochortsaufgelösten Punktanalysen und nasschemischen Gesamterzmessungen mineralogische und geochemische Untersuchungen durchgeführt. Die Datenbank beinhaltet aggregierte Daten von 17.000 geochemischen Datensätzen, Informationen zur regionaler Infrastruktur und möglichen Umweltrisiken, sowie Ergebnisse aus innovativen, rohstoffeffizienten Aufbereitungsversuchen. Unter Verwendung aller Ergebnisse können interaktive Karten zu neuen HT-Metall-Rohstoffpotenzialen erzeugt werden.

Hinsichtlich der regionalen Verteilung der HT-Spurenmetalle zeigen sich Abhängigkeiten der Gehalte im Erz zum genetischen Lagerstättentyp. Sphalerit aus der SEDEX-Lagerstätte „Rammelsberg“ sowie aus Skarn-Lagerstätten des Erzgebirges beinhaltet erhöhte Indium-Gehalte (Median 14-119 ppm). Im Gegensatz dazu zeigt Sphalerit aus der SEDEX-Lagerstätte „Meggen“ nur sehr geringe HT-Spurenmetallgehalte. Germanium ist in „Schalenblenden“ aus MVT-Lagerstätten das vorherrschende HT-Spurenelement (Median 29-147 ppm). Allerdings ist kristalliner Sphalerit aus diesen Vorkommen durch geringe Germanium-Gehalte charakterisiert. Sphalerit aus allen untersuchten hydrothermalen Ganglagerstätten ist durch moderate bis hohe Gallium-Konzentrationen (Median 6-81 ppm) gekennzeichnet. Die Germanium- und Indium-Gehalte

\footnotetext{
*Addresses of the authors:

${ }^{1}$ Federal Institute for Geosciences and Natural Resources (BGR), Stilleweg 2, 30655 Hannover, Germany (soeren-henning@gmx. de)

${ }^{2}$ Clausthaler Umwelttechnik Forschungszentrum (CUTEC), TU Clausthal, Leibnizstraße 23, 38678 Clausthal-Zellerfeld, Germany

${ }^{3}$ Institute for Mineralogy, Leibniz University Hannover, Callinstraße 3, 30167 Hannover, Germany
} 
variieren dagegen signifikant, abhängig von der Metallquelle sowie den Fluideigenschaften. Ganglagerstätten aus dem Ruhrgebiet und dem Schwarzwald beinhalten Sphalerit mit erhöhten Germanium-Gehalten (Median 55-73 ppm), während Sphalerit aus Gängen des Erzgebirges durch erhöhte Indium-Konzentrationen (Median 33 ppm) charakterisiert ist.

Die Ergebnisse dieser Arbeit zeigen, dass die HT-Spurenelementgehalte in den Buntmetallsulfiden nicht ausschließlich vom genetischen Lagerstättentyp abhängig sind. Auch die lokal variierenden geologischen Bedingungen, wie beispielsweise die Ausgangsgesteine, Fluidbedingungen sowie das Vorhandensein von organischer Materie, haben einen bedeutenden Einfluss auf die Spurenelementanreicherungen. Im Gegensatz zu den eher lokalen Quellen für Gallium sind für Indium und Germanium in den untersuchten Systemen auch weiter entfernte Reservoirs als Quelle zu diskutieren.

Keywords: germanium, gallium, indium, sphalerite, database, Germany, hydrothermal veins, MVT, SHMS, skarn, deposits, economic geology

Schlüsselwörter: Germanium, Gallium, Indium, Sphalerit, Datenbank, Deutschland, hydrothermale Gänge, MVT, SEDEX, Skarn, Lagerstätten, Rohstoffgeologie

\section{Introduction}

Mining on non-ferrous metals has a long history in Germany's ore districts. Early prospecting work and mining on lead and silver ores during the Roman period and the Middle Ages, is assumed (Geurts et al. 2004; Werner \& Dennert 2004). Mining of base metals in Germany discontinued in the late $20^{\text {th }}$ century due to decreasing ore grades and low commodity prices (Stedingk 2012). Result of the complete stop of activities in this field is an overall under exploration of the important mining districts in Germany in terms of modern geochemical analysis.

Today, the steadily rising demand for metals worldwide and the advancing development of modern technologies place new demands on the exploration and production of raw materials. Elements for high tech applications (HT elements) such as germanium $(\mathrm{Ge})$, gallium $(\mathrm{Ga})$ and indium $(\mathrm{In})$ gain rising importance. These critical raw materials frequently occur at trace levels incorporated in base metal sulphides such as sphalerite and chalcopyrite, or as small mineral inclusions of, for example, roquesite, gallite or germanite (Cook et al. 2009).

Currently, Ge is economically the most important of the HT trace elements studied here and can be enriched in sphalerite with concentrations up to $3000 \mathrm{ppm}$ (Bernstein 1985; Cook et al. 2009; Belissont et al. 2014). Owing to its characteristics as semiconductor element and its infrared transmission properties, the main applications are in infrared optics, fibre optic cables, catalysts and solar applications (Melcher \& Buchholz 2013; Marscheider-Weidemann et al. 2016). Gallium is incorporated in sphalerite with concentrations up to thousands of ppm (Cook et al. 2009; Marscheider-Weidemann et al. 2016). It is used as a semiconductor element in the electronics industry (e.g. LEDs, solar applications) and is commonly extracted from bauxite ores. However, its occurrence and incorporation in sulphides are less well investigated. Indium is preferentially used in various thin-film applications such as transparent electrodes for displays and semiconductor layers in solar applications (Marscheider-Weidemann et al. 2016). Sphalerite hosts up to thousands of ppm of In in several ore deposits worldwide (Schwarz-Schampera \& Herzig 2002; Seifert \& Sandmann 2006).
Despite the enormous interest in these elements worldwide, there are no systematic studies on HT trace elements in German ore districts available so far. Furthermore, the reliability of the sparse trace element data from times of active base metal mining in Germany is insufficient also due to outdated analytical methods used in the past. However, the fact that In was extracted from the sediment-hosted massive sulphide (SHMS) deposit "Rammelsberg" (Harz) from 19481964 as a by-product (mine closure in 1988), indicates elevated contents of this trace element in some of its ore types (Mehner 1993). Potentials of base metal ores in Germany for HT trace elements were also suggested in some recent studies. Skarn deposits from the Erzgebirge yielded elevated In contents (Seifert \& Sandmann 2006). Mostly moderate concentrations of $\mathrm{Ge}$ and $\mathrm{Ga}$ were measured in a few sphalerite samples from a small number of hydrothermal vein deposits in Germany and a Mississippi-Valley-Type (MVT) deposit in the Odenwald region (e.g. Möller \& Dulski 1993; Werner et al. 2002; Pfaff et al. 2011). Finally, studies on base metal deposits in the EU and worldwide indicate a dependency of enrichment of the HT trace elements on the genetic deposit type and also on the formation temperature (Cook et al. 2009; Ye et al. 2011; Frenzel et al. 2016).

The overall objective of the present study was the evaluation of raw material potentials for Ge-, Ga- and In-extraction as important by-products of mining in Germany's base metal mining districts. Geochemical data for ore samples from the adjacent EU region Plombières in Belgium are added for scientific comparison. The main focus of the work is to provide active support for future exploration activities. Therefore, a high tech metal-oriented database was set up summarising state-of-the-art data on ore mineralogy and chemistry (primary indicators), historic mining site-related infrastructural (secondary) indicators and mineral processing-related (tertiary) indicators. The produced mineralogical and geochemical data sets for ore samples from eleven important mining districts of Germany, e.g. data from "micro-energy-disperse X-ray fluorescence microscopy" ( $\mu$-EDXRF), "laser ablation inductively coupled plasma mass spectrometry" (LA-ICP-MS) and "electron micro probe analyser" (EMPA), are also scientifically interpreted with focus on trace element concentration and distribution characteristics in base metal deposits of different genetic 
types. Results are discussed to reveal a possible influence of the geological framework on observed regional enrichment or depletion of HT trace metals in the base metal ores.

\section{Geology and sampling}

Fig. 1 illustrates the locations of the investigated eleven base metal mining districts in Germany and Belgium. These districts were subdivided into 35 clusters of deposits (A-AI) in terms of geographical and geological aspects (Table 1). In this study, five genetic base metal deposit types are distinguished: (a) Sediment-hosted massive sulphide deposits (SHMS), (b) skarn deposits (SKARN), (c) hydrothermal vein deposits (VEIN), (d) carbonate-hosted Mississippi-Valley-Type deposits (MVT), and (e) disseminated ore deposits (DISSEM). Although regional differences in the geological framework of the deposits are obvious, all mining districts are located in the Variscan mountain belt that was mainly formed in the Devonian and Carboniferous due to the colli-

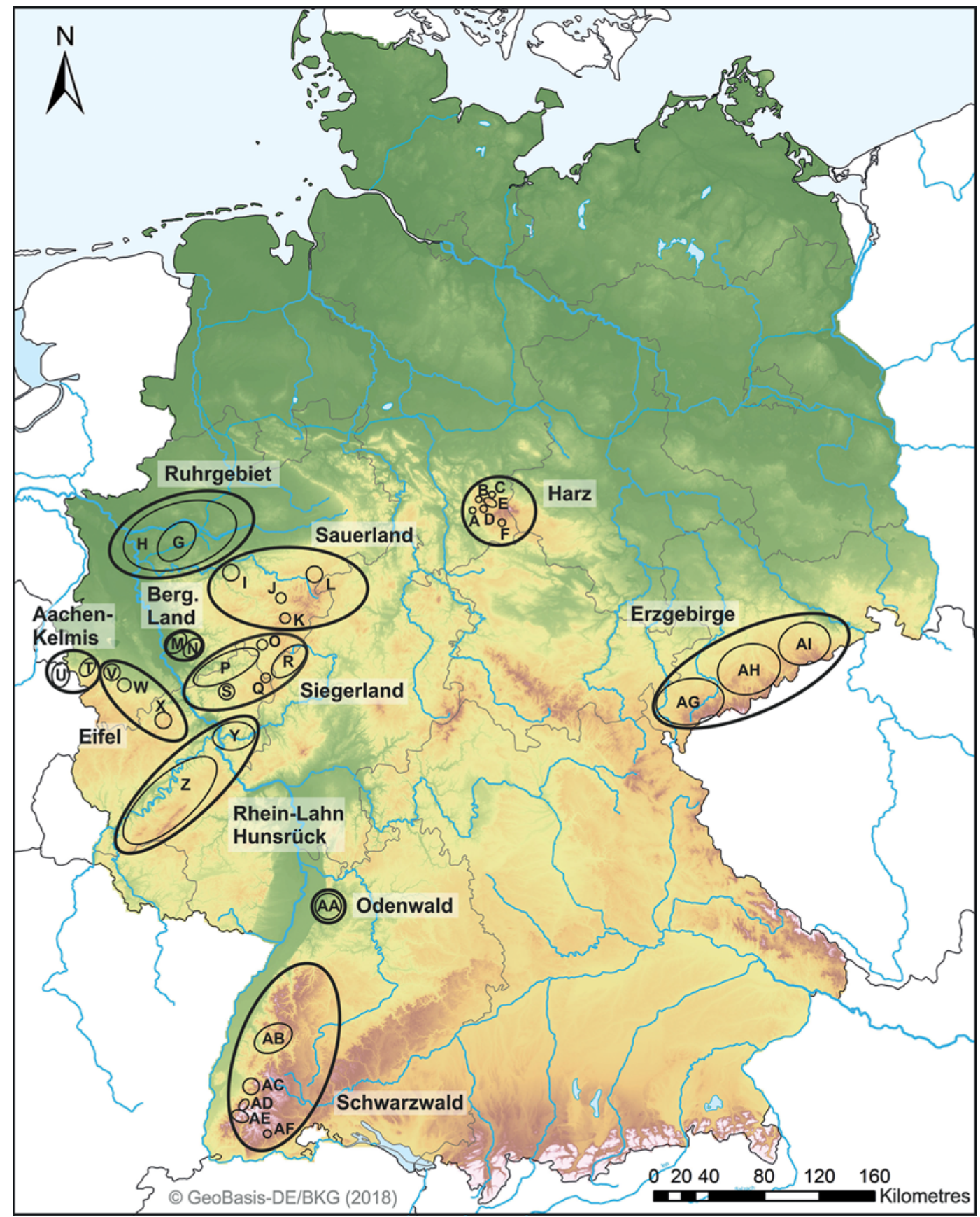

Fig. 1: Geomorphological map of Germany showing the locations of the eleven ore districts and 35 clusters of deposits (A-AI) included in the HTMET database (see also Table 1 for further details). 
Table 1: List of clusters (A-AI), deposit types and mineral paragenesis, as well as numbers of investigated locations and samples included

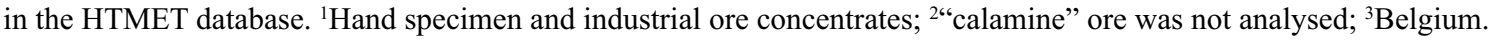

\begin{tabular}{|c|c|c|c|c|c|c|}
\hline \multicolumn{2}{|c|}{$\begin{array}{l}\text { Ore } \\
\text { district }\end{array}$} & \multirow[t]{2}{*}{ Cluster } & \multirow[t]{2}{*}{$\begin{array}{l}\text { Loca- } \\
\text { tions }\end{array}$} & \multirow[t]{2}{*}{$\begin{array}{l}\text { Deposit } \\
\text { type }\end{array}$} & \multirow[t]{2}{*}{ Mineral paragenesis } & \multirow[t]{2}{*}{$\begin{array}{l}\text { No. of } \\
\text { samples } 1\end{array}$} \\
\hline 1 & Harz & & & & & \\
\hline & A & Grund ore mine & 1 & VEIN & quartz-calcite-siderite veins; $\mathrm{Pb}-\mathrm{Zn}(-\mathrm{Cu})$ ore & 44 \\
\hline & B & Lautenthal & 1 & VEIN & quartz and calcite veins; $\mathrm{Zn}-\mathrm{Pb}-\mathrm{Cu}$ ore & 35 \\
\hline & $\mathrm{C}$ & Rammelsberg & 1 & SHMS & polymetallic $\mathrm{Zn}-\mathrm{Cu}-\mathrm{Fe}-\mathrm{Pb}$ ore; barite & 14 \\
\hline & $\mathrm{D}$ & Clausthal-Zellerfeld & 5 & VEIN & quartz and calcite veins; $\mathrm{Pb}-\mathrm{Zn}(-\mathrm{Cu})$ ore & 14 \\
\hline & $\mathrm{E}$ & Bockswiese & 4 & VEIN & quartz-carbonate veins; $\mathrm{Zn}-\mathrm{Pb}-\mathrm{Cu}$ ore & 8 \\
\hline & $\mathrm{F}$ & St. Andreasberg & 3 & VEIN & quartz-calcite veins; $\mathrm{Zn}-\mathrm{Pb}$ ore / barite veins; $\mathrm{Zn}-\mathrm{Cu}$ ore & 6 \\
\hline \multirow[t]{3}{*}{2} & \multicolumn{6}{|c|}{ Ruhrgebiet } \\
\hline & G & Core zone & 7 & VEIN & quartz-barite-carbonate veins; $\mathrm{Pb}-\mathrm{Zn}(-\mathrm{Cu})$ ore; hard coal & 30 \\
\hline & $\mathrm{H}$ & Marginal zone & 4 & VEIN & quartz-barite-carbonate veins; $\mathrm{Pb}-\mathrm{Zn}(-\mathrm{Cu})$ ore; hard coal & 4 \\
\hline \multirow[t]{5}{*}{3} & \multicolumn{6}{|c|}{ Sauerland } \\
\hline & I & Iserlohn & 1 & VEIN & carbonate hosted $\mathrm{Pb}-\mathrm{Zn}$ ore & 4 \\
\hline & $\mathrm{J}$ & Ramsbeck & 1 & VEIN & quartz veins; $\mathrm{Pb}-\mathrm{Zn}$ ore & 11 \\
\hline & K & Meggen & 1 & SHMS & polymetallic Fe- $\mathrm{Pb}-\mathrm{Zn}$ ore; barite & 10 \\
\hline & $\mathrm{L}$ & Brilon $^{2}$ & & & $\mathrm{~Pb}-\mathrm{Zn}$ ore ("calamine") & \\
\hline \multirow[t]{3}{*}{4} & \multicolumn{6}{|c|}{ Bergisches Land } \\
\hline & M & Bensberg $\mathrm{Pb}-\mathrm{Zn}$ area & 7 & VEIN & quartz(-carbonate) veins; $\mathrm{Pb}-\mathrm{Zn}(-\mathrm{Cu})$ ore & 25 \\
\hline & $\mathrm{N}$ & Bergisch $\mathrm{Pb}-\mathrm{Zn}$ area & 4 & VEIN & quartz-carbonate veins; $\mathrm{Pb}-\mathrm{Zn}(-\mathrm{Cu})$ ore & 9 \\
\hline \multirow[t]{6}{*}{5} & \multicolumn{6}{|c|}{ Siegerland } \\
\hline & $\mathrm{O}$ & Müsen & 1 & VEIN & siderite-quartz veins; $\mathrm{Cu}-\mathrm{Zn}-\mathrm{Pb}$ ore & 2 \\
\hline & $P$ & Siegen & 7 & VEIN & siderite-quartz veins; $\mathrm{Pb}-\mathrm{Zn}-\mathrm{Cu}(-\mathrm{Ni})$ ore & 12 \\
\hline & Q & Burbach & 1 & VEIN & siderite-quartz-veins; $\mathrm{Pb}-\mathrm{Zn}$-Ni-Co ore & 4 \\
\hline & $\mathrm{R}$ & Lahn-Dill & 2 & VEIN & siderite veins; $\mathrm{Pb}-\mathrm{Zn}$ ore / quartz veins; $\mathrm{Pb}-\mathrm{Sb}-\mathrm{Cu}$ ore & 4 \\
\hline & $\mathrm{S}$ & $\operatorname{Hamm}(\mathrm{Sieg})$ & 1 & VEIN & siderite veins; $\mathrm{Pb}-\mathrm{Zn}$ ore & 2 \\
\hline \multirow[t]{3}{*}{6} & \multicolumn{6}{|c|}{ Aachen-Kelmis } \\
\hline & $\mathrm{T}$ & Aachen-Stolberg & 2 & MVT & carbonate hosted $\mathrm{Pb}-\mathrm{Zn}(-\mathrm{Fe})$ ore & 10 \\
\hline & $\mathrm{U}$ & Plombières-Kelmis ${ }^{3}$ & 9 & MVT & carbonate hosted $\mathrm{Pb}-\mathrm{Zn}(-\mathrm{Fe})$ ore & 25 \\
\hline \multirow[t]{4}{*}{7} & \multicolumn{6}{|l|}{ Eifel } \\
\hline & $\mathrm{V}$ & Maubach & 1 & DISSEM & dissiminated $\mathrm{Pb}(-\mathrm{Zn}-\mathrm{Cu})$ ore & 2 \\
\hline & $\mathrm{W}$ & Mechernich & 1 & DISSEM & dissiminated $\mathrm{Pb}(-\mathrm{Zn})$ ore & 1 \\
\hline & $\mathrm{X}$ & Adenau & 1 & VEIN & siderite-quartz veins; $\mathrm{Pb}-\mathrm{Zn}$ ore & 1 \\
\hline \multirow[t]{3}{*}{8} & \multicolumn{6}{|c|}{ Rhein-Lahn-Hunsrück } \\
\hline & Y & Rhein-Lahn & 12 & VEIN & quartz-siderite veins; $\mathrm{Pb}-\mathrm{Zn}-\mathrm{Cu}$ ore & 39 \\
\hline & $\mathrm{Z}$ & Hunsrück & 7 & VEIN & quartz-carbonate veins; $\mathrm{Pb}-\mathrm{Zn}-\mathrm{Cu}$ ore & 26 \\
\hline \multirow[t]{2}{*}{9} & \multicolumn{6}{|c|}{ Odenwald } \\
\hline & AA & Odenwald & 1 & MVT & carbonate hosted $\mathrm{Pb}-\mathrm{Zn}(-\mathrm{Fe})$ ore & 9 \\
\hline 10 & \multicolumn{6}{|c|}{ Schwarzwald } \\
\hline & $\mathrm{AB}$ & Kinzigtal & 3 & VEIN & fluorite-barite veins; $\mathrm{Pb}-\mathrm{Zn}-\mathrm{Cu}(-\mathrm{Ag})$ ore & 10 \\
\hline & $\mathrm{AC}$ & Glottertal-Suggental & 4 & VEIN & barite veins; $\mathrm{Pb}-\mathrm{Zn}-\mathrm{Cu}$ ore / quartz-siderite veins; $\mathrm{Zn}-\mathrm{Pb}-\mathrm{Cu}$ ore & 4 \\
\hline & $\mathrm{AD}$ & Schauinsland & 2 & VEIN & quartz-barite-carbonate veins; $\mathrm{Zn}-\mathrm{Pb}$ ore & 33 \\
\hline & $\mathrm{AE}$ & Münstertal & 7 & VEIN & $\begin{array}{l}\text { quartz-barite veins; } \mathrm{Pb}-\mathrm{Zn} \text { ore / fluorite-barite veins; } \mathrm{Zn}-\mathrm{Pb} \\
(-\mathrm{Cu}) \text { ore; fluorite veins; } \mathrm{Ag}-\mathrm{As}-\mathrm{Sb} \text { ore }\end{array}$ & 25 \\
\hline & $\mathrm{AF}$ & St. Blasien & 1 & VEIN & fluorite-barite veins; $\mathrm{Zn}-\mathrm{Pb}-\mathrm{Cu}$ ore & 4 \\
\hline
\end{tabular}


Table 1: cont.

\begin{tabular}{|c|c|c|c|c|c|c|}
\hline \multicolumn{2}{|c|}{$\begin{array}{l}\text { Ore } \\
\text { district }\end{array}$} & Cluster & $\begin{array}{l}\text { Loca- } \\
\text { tions }\end{array}$ & $\begin{array}{l}\text { Deposit } \\
\text { type }\end{array}$ & Mineral paragenesis & $\begin{array}{l}\text { No. of } \\
\text { samples }^{1}\end{array}$ \\
\hline \multirow[t]{7}{*}{11} & \multicolumn{6}{|c|}{ Erzgebirge } \\
\hline & \multirow[t]{2}{*}{$\mathrm{AG}$} & Western part & 8 & SKARN & $\mathrm{Fe}-\mathrm{Zn}$ ore / $\mathrm{Zn}-\mathrm{Cu}$ ore $/ \mathrm{Sn}-\mathrm{Zn}-\mathrm{Cu}$ ore and magnetite & 18 \\
\hline & & & 1 & VEIN & quartz veins; Sn ore & 1 \\
\hline & \multirow[t]{3}{*}{$\mathrm{AH}$} & Central part & 1 & SKARN & Sn ore & 13 \\
\hline & & & 2 & MVT & carbonate hosted $\mathrm{Pb}-\mathrm{Zn}$ ore & 5 \\
\hline & & & 1 & VEIN & $\begin{array}{l}\text { quartz veins; } \mathrm{Pb}-\mathrm{Zn}-\mathrm{Sn}-\mathrm{As} \text { ore / carbonate-quartz veins; } \mathrm{Zn}-\mathrm{Pb} \text { - } \\
\mathrm{Sb} \text { ore }\end{array}$ & 8 \\
\hline & $\mathrm{AI}$ & Eastern part & 2 & SKARN & $\mathrm{Fe}$ ore / magnetite and $\mathrm{Zn}-\mathrm{Cu}$ ore & 4 \\
\hline
\end{tabular}

sion of Laurussia and Gondwana during the formation of Pangaea. As the majority of the deposits selected for investigation are not accessible anymore, most of the samples were taken from geological collections of the Federal Institute for Geosciences and Natural Resources (BGR), associated partners and private mineral collectors. Sampling campaigns in mining museums, like the "Lautenthals Glück" mine (Harz) and several abandoned mines in the Schwarzwald district have been realised thanks to active support by local state geological surveys and museum operators. If present, differences in the sampled ore type and the ore appearance (e.g. grain-sizes of sulphides or associated gangue minerals) were considered during sampling.

\section{Methods}

\subsection{Analytical methods}

\subsection{1 $\mu$-EDXRF}

Energy dispersive X-ray fluorescence spectrometry maps ( $\mu$-EDXRF) were carried out using the M4 Tornado by Bruker to obtain an overview on the textural properties and the mineral proportions of larger cut rock slices (max. $16 \mathrm{x}$ $20 \mathrm{~cm}$ ). The X-ray beam of the Rh-tube is focused on the sample surface with a $51^{\circ}$ angle and approx. $17 \mu \mathrm{m}$ diameter in spot size at $17.48 \mathrm{keV}$. Mapping of the samples with maximum excitation (tube: $50 \mathrm{kV}, 600 \mu \mathrm{A}$ ), 2 ms measuring time per spot and step ranges between 20 to $50 \mu \mathrm{m}$ leads to spatially resolved analytical data, with elements heavier than $\mathrm{Na}$ measurable under low vacuum conditions (Flude et al. 2017). Mineral distribution maps were obtained by supervised classification using the "Spectral Angle Mapper" algorithm (Nikonow \& Rammlmair 2017). An endmember database for base metal sulphides and associated minerals in the above deposit types was created. Unclassified areas (mostly silicates) were assigned to the host rock. Mixed analysis and boundary effects, as well as diffraction effects for the interpretation of the mineral distribution maps were considered during manual spectrum interpretation and endmember definition (Nikonow \& Rammlmair 2016). This method provides a link between micro-scale geochemistry data and macro-scale ore outcrops and rock specimen. Based on the $\mu$-EDXRF results smaller pieces $(3 \times 3 \mathrm{~cm})$ from the original rock slices were cut and prepared as polished sections, which were used as samples for LA-ICP-MS and EMPA analysis (details see below).

\subsubsection{LA-ICP-MS}

The quantitative analysis of major, minor and trace elements in sphalerite and chalcopyrite was conducted in-situ by a PlasmaQuant Elite quadrupole ICP-MS by Analytik Jena coupled to a $213 \mathrm{~nm}$ laser ablation system (LSX-213 G2+ by CETAC Technologies). The laser system was adjusted to ablate round $40 \mu \mathrm{m}$ spots using a fluence of $8 \mathrm{~J} / \mathrm{cm}^{2}$ at $20 \mathrm{~Hz}$ for $15 \mathrm{~s}$. Prior to each ablated spot a gas blank was monitored for $15 \mathrm{~s}$. On each sample (polished sections, see above) 30 to 60 spots on sphalerite and chalcopyrite were analysed. Helium was used as the carrier gas $(0.4 \mathrm{l} / \mathrm{min})$. Cool, auxiliary and sample gas flows of the ICP-MS were adjusted to 9.0, 1.35 and $1.041 \mathrm{Ar} / \mathrm{min}$, respectively. The isotopes ${ }^{34} \mathrm{~S},{ }^{44} \mathrm{Ca}$, ${ }^{51} \mathrm{~V},{ }^{52} \mathrm{Cr},{ }^{55} \mathrm{Mn},{ }^{56,57} \mathrm{Fe},{ }^{59} \mathrm{Co},{ }^{60} \mathrm{Ni},{ }^{63,65} \mathrm{Cu},{ }^{66} \mathrm{Zn},{ }^{71} \mathrm{Ga},{ }^{74} \mathrm{Ge}$, ${ }^{75} \mathrm{As},{ }^{77,78,82} \mathrm{Se},{ }^{83} \mathrm{Kr},{ }^{95} \mathrm{Mo},{ }^{107} \mathrm{Ag},{ }^{111} \mathrm{Cd},{ }^{115} \mathrm{In},{ }^{117,118} \mathrm{Sn},{ }^{121} \mathrm{Sb}$, ${ }^{126} \mathrm{Te},{ }^{137} \mathrm{Ba},{ }^{205} \mathrm{Tl}$ and ${ }^{208} \mathrm{~Pb}$ were monitored by the ICP-MS using a dwell time of $10 \mathrm{~ms}$ for each isotope. In the analytical sessions, the sphalerite reference material MUL-ZnS-1 (Onuk et al. 2017) and the polymetallic reference material MASS-01 (Danyushevsky et al. 2011) were ablated several times. Element concentrations in sphalerite were quantified using MUL-ZnS-1 as an external calibration material and MASS-01 as reference material for quality control (Wilson et al. 2002; Yuan et al. 2012). Element concentrations in chalcopyrite were quantified using MASS-01 as an external calibration material. Raw data were exported and processed with a data-handling software tool (Gäbler et al. 2011). A calibration strategy based on ablation yield correction factors (Liu et al. 2008) was used, in which the sum of all cations was normalised to the stoichiometric content of $\mathrm{Zn}$ in sphalerite (67.00 wt.\%) and the stoichiometric content of $\mathrm{Cu}$ and $\mathrm{Fe}$ in chalcopyrite (65.06 wt.\%). This calibration strategy eliminates the need for additional element analysis at each spot for internal standardisation by an independent 
method (e.g. by EMPA) and enables the analysis of a higher number of samples (Danyushevsky et al. 2011).

Isobaric interference needs to be considered when analysing trace elements in sphalerite by LA-ICP-MS (Cook et al. 2009; Danyushevsky et al. 2011; Belissont et al. 2014). The interference of ${ }^{115} \mathrm{Sn}$ on ${ }^{115} \mathrm{In}$ was corrected using ${ }^{117} \mathrm{Sn}$. The isotope ${ }^{74} \mathrm{Ge}$ was used for determination of the Ge concentration because this isotope shows least isobaric interference caused by other relevant ions and the highest natural abundance of all Ge isotopes. Although no collision cell was used, a large influence of ${ }^{40} \mathrm{Ar}^{34} \mathrm{~S}$ on ${ }^{74} \mathrm{Ge}$ intensities can be excluded due to the record of Ge concentrations below the detection limit for many laser spots in sphalerite and chalcopyrite. A typical analytical uncertainty for laser ablation of no more than $20-30 \%$ is expected for the analysed element concentrations (Cook et al. 2009; Danyushevsky et al. 2011). Single spots with clear indications of mixed mineral analyses involving underlying minerals or mineral inclusions (ragged spectrum) were excluded.

The average detection limits of LA-ICP-MS analysis are $1 \mathrm{ppm}$ for Ga, $2 \mathrm{ppm}$ for Ge and $0.1 \mathrm{ppm}$ for In. The reliability of the used analytical method was verified by re-measurement of selected samples with a larger number of laser spots and by comparative measurements at the Montanuniversität Leoben (Austria), where a quantification method based on sulphur concentrations as internal standard was applied. Exemplary, the concentrations of the major elements were also compared with electron microprobe data for several samples. However, box plot diagrams indicate that the natural variability of trace element concentrations in sphalerite covers several orders of magnitudes and is as such much larger than the analytical uncertainty. Nevertheless, measurement of a given sample is reproducible and distinct differences between samples can be illustrated by their populations within box plot diagrams.

\subsubsection{EMPA}

Fine-grained samples and sphalerite grains containing intense chalcopyrite disease could not be analysed by LA-ICP-MS due to the selected spot size of $40 \mu \mathrm{m}$. These samples were measured by a Jeol JXA-8530F Hyperprobe (FEG-EMPA) where smaller spot sizes of about $1-2 \mu \mathrm{m}$ are applied. The analytical setup was similar to that used by Goldmann et al. (2018). The quantitative analysis of the ma- jor, minor and trace element compositions of sphalerite and chalcopyrite grains were conducted by single spot analyses using wavelength-dispersive spectrometry with an acceleration voltage of $20 \mathrm{kV}$ and a beam current of $80 \mathrm{nA}$. Major elements were analysed for 8-40 s applying $\mathrm{ZnS}$ as reference material for $\mathrm{Zn}$ and $\mathrm{S}, \mathrm{CuFeS}_{2}$ for $\mathrm{Cu}$ and $\mathrm{FeS}$ for $\mathrm{Fe}$ using their respective $\mathrm{K} \alpha \mathrm{X}$-ray lines. Minor and some trace element signals were counted for $60-120 \mathrm{~s}$ using a PET crystal for In-L $\alpha$ and a LIF crystal for Ge-K $\alpha$ and Ga-K $\alpha$. For calibration, $\mathrm{GaAs}$ as well as pure metals (In and $\mathrm{Ge}$ ) were used as reference materials. The limits of detection for $\mathrm{Ge}$ $(30 \mathrm{ppm}), \mathrm{Ga}(23 \mathrm{ppm})$ and In $(24 \mathrm{ppm})$ are much higher compared to those of the LA-ICP-MS method.

\subsubsection{Bulk ore geochemistry}

In order to estimate the trace element compositions of different ore types in the base metal deposits and occurrences and to cross-check the results of the mineral chemistry determinations by LA-ICP-MS, geochemical bulk sample analysis was conducted. Per location and ore type up to $100 \mathrm{~g}$ of sample material knocked off several hand specimen was crushed and enriched to $25-100 \mathrm{wt} . \%$ sulphide content by hand picking, resulting in $\mathrm{Zn}-, \mathrm{Cu}$ - or mixed-"sample concentrates". The quantitative determination of major, minor and trace elements was carried out in the laboratories of Actlabs (Canada) using the analytical packages "Ultratrace 3" (INAA + 4-acid digestion/ICP-OES/ICP-MS), "Ultratrace 7" (peroxide fusion - ICP and ICP/MS) and "Code 8-Peroxide-ICP-OES". Precision and accuracy are ensured by blank runs, in-house control, duplicate analysis and a suite of internationally certified standards. Furthermore, industrial concentrates deriving from the historic ore processing plants were analysed by ICP-OES (aqua regia digestion) at TU Clausthal (IFAD Institute). Sulphur was measured by use of an infrared cell here and $\mathrm{Ge}$ concentrations were analysed by use of multistep digestion (nitric acid) to avoid Ge loss.

\subsection{Definition of ore types and data handling}

According to the mineralogical compositions of the ores, seven major ore types were defined based on the sulphide mineral proportions as estimated by $\mu$-EDXRF maps (Table

Table 2: Ore types in studied base metal samples based on $\mu$-EDXRF mineral distribution maps; the types are independent of the genetic deposit type; proportions are in wt.\% and are referred to sulphide contents.

\begin{tabular}{ll}
\hline Ore type & Definition \\
\hline sphalerite-dominated & sphalerite $>90 \mathrm{wt.} \%$ \\
sphalerite-galena & sphalerite + galena $>90 \mathrm{wt} . \%$, sphalerite $<90 \mathrm{wt.} \%$ and galena $<90 \mathrm{wt} \%$ \\
sphalerite-chalcopyrite & sphalerite + chalcopyrite $>90 \mathrm{wt} . \%$, sphalerite $<90 \mathrm{wt} . \%$ and chalcopyrite $<90$ wt. $\%$ \\
sphalerite-galena-chalcopyrite & sphalerite + galena $>25 \mathrm{wt} \% \%$ and chalcopyrite $>25 \mathrm{wt} . \%$ \\
chalcopyrite-dominated & chalcopyrite $>90 \mathrm{wt} . \%$ \\
galena-dominated & galena $>90 \mathrm{wt.} \%$, sphalerite-bearing \\
fahlore-bearing/-dominated & occurrence of larger amounts of fahlore, chalcopyrite-bearing \\
\hline
\end{tabular}


2). This classification is independent of the genetic deposit type. As literature data (e.g. Cook et al. 2009) and first studies have shown that sphalerite and chalcopyrite form the major carriers of the HT trace metals in base metal sulphide ores, the mineralogical and geochemical work of this project mainly focused on these minerals. The mineral chemistry data (LA-ICP-MS, EMPA) stored in the database consist of aggregated data for each deposit further subdivided into the separated ore types (see Figure $3 b$ ). These aggregated data describe the obtained distributions of element concentrations within each ore type of each deposit. The $25^{\text {th }}, 50^{\text {th }}$ (median) and $75^{\text {th }}$ percentiles, as well as an average value (calculated arithmetic mean), are used. Data for sphalerite and chalcopyrite are given separately. The underlying numbers of samples, analysed single spots, and the applied analytical technique are given for each distribution as well.

\section{Results and discussion}

\subsection{High tech trace element database "HTMET"}

\subsubsection{Database structure}

The aim of the HTMET database is to conveniently manage the extensive and complex data stock and to enable the evaluation of raw material potentials for the above mentioned 35 clusters of base metal deposits as a fundamental basis for future exploration activities. Therefore, a relational database was set up to store and handle mineralogical and geochemical data (ore-related primary indicators) as well as mine site-related secondary and mineral processing-related tertiary indicators. For the purpose of data access and visualisation a graphical user interface including a multicriterial evaluation tool has been developed as a front end to the database.

A python-based importer software reads all data and converts it from MS Excel to PostgreSQL format. The data is stored normalised in the database and PostgreSQL. Postgis is used to support GIS-based queries. The design is data driven, which means that additional data types can easily be added to the database, mostly without the need to change the database scheme. Fine-grained access rights are implemented to support federal state-based access. Each individual deposit, which can be selected either by a search function or from a list of deposits, is unambiguously allocated to a cluster, district, federal state and country (Fig. 2). Primary indicators are included for most deposits and contain:

(1) General data such as the genetic ore deposit type, a short description of the mineral paragenesis and the mining history as well as associated gangue minerals (barite, fluorite and calcite) and other raw materials, possibly harmful minerals (marcasite and arsenopyrite), an image of a typical ore sample, the exact geographical location of the mine site and links to further literature.

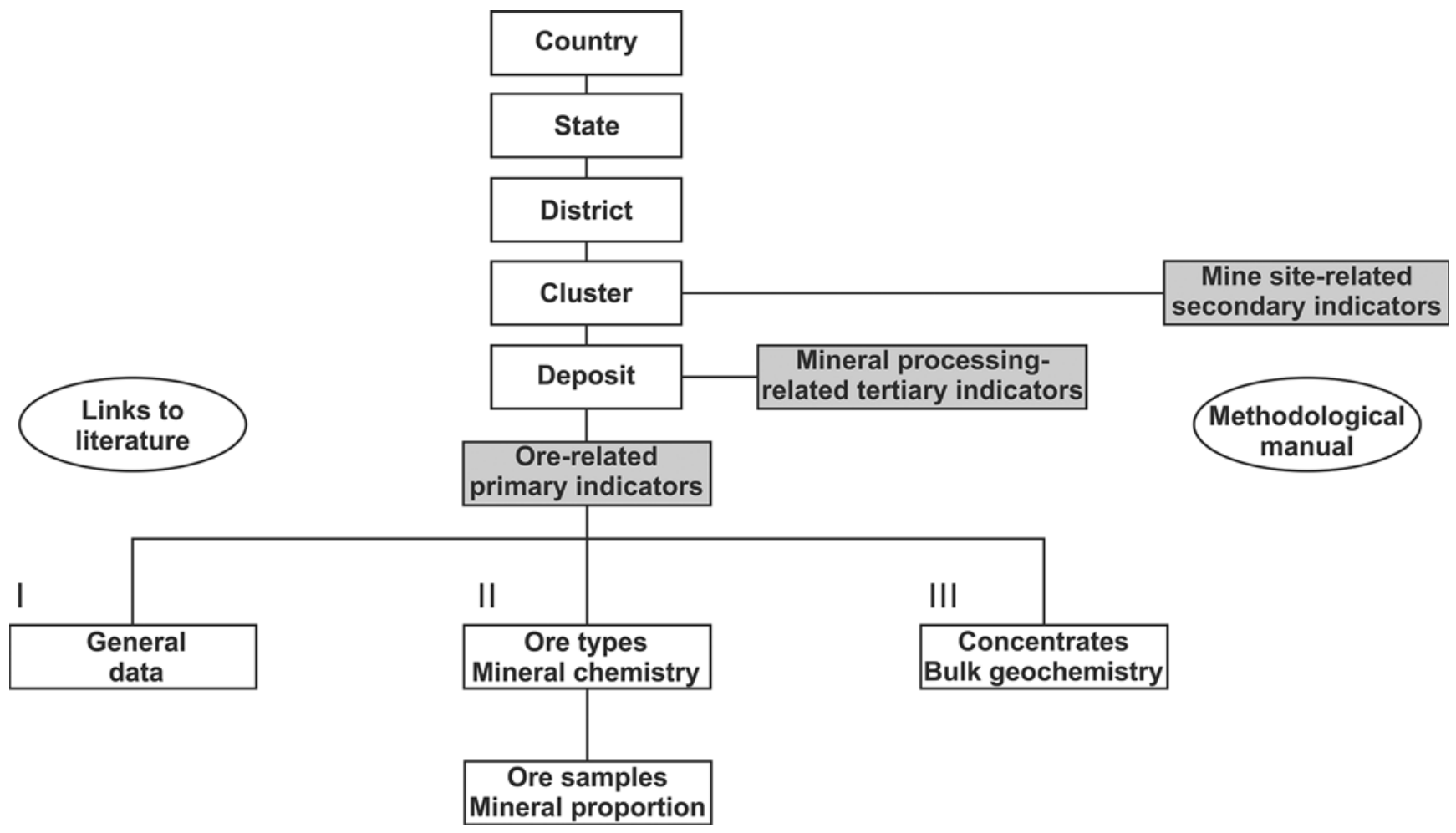

Fig. 2: Schematic structure of the HTMET database showing stored contents and connections between primary, secondary and tertiary indicators. 
(2) Aggregated mineral chemistry results (LA-ICP-MS, EMPA data based on 17,000 data sets and 457 samples) with special consideration of minor and HT trace elements of the related ore samples ( $\mu$-EDXRF data, 457 samples).

(3) Bulk geochemistry results of selected industrial and sample concentrates (ICP-MS/OES data, 101 ore concentrates)

Detailed descriptions and the corresponding literature for each of the methods used are included in the database (methodological manual). Literature data on outdated geochemical results and sporadic hints on remaining amounts of mineral/metal resources are not included in the database due to large differences in the quality of the data (however, all available references for both are provided for further studies of the users).

Secondary indicators were included for eight clusters of deposits. They focus on an evaluation of infrastructure and environmental aspects within the defined clusters of important mine sites, such as:

(1) Accessibility of the cluster area (railway, main roads or river ports).

(2) Summary of the legal situations at individual mine sites (e.g. historic monuments, sensitive uses of sites, priority areas for resource extraction).

(3) Regional constraints (e.g. availability of energy, water, skilled personnel, processing industry).

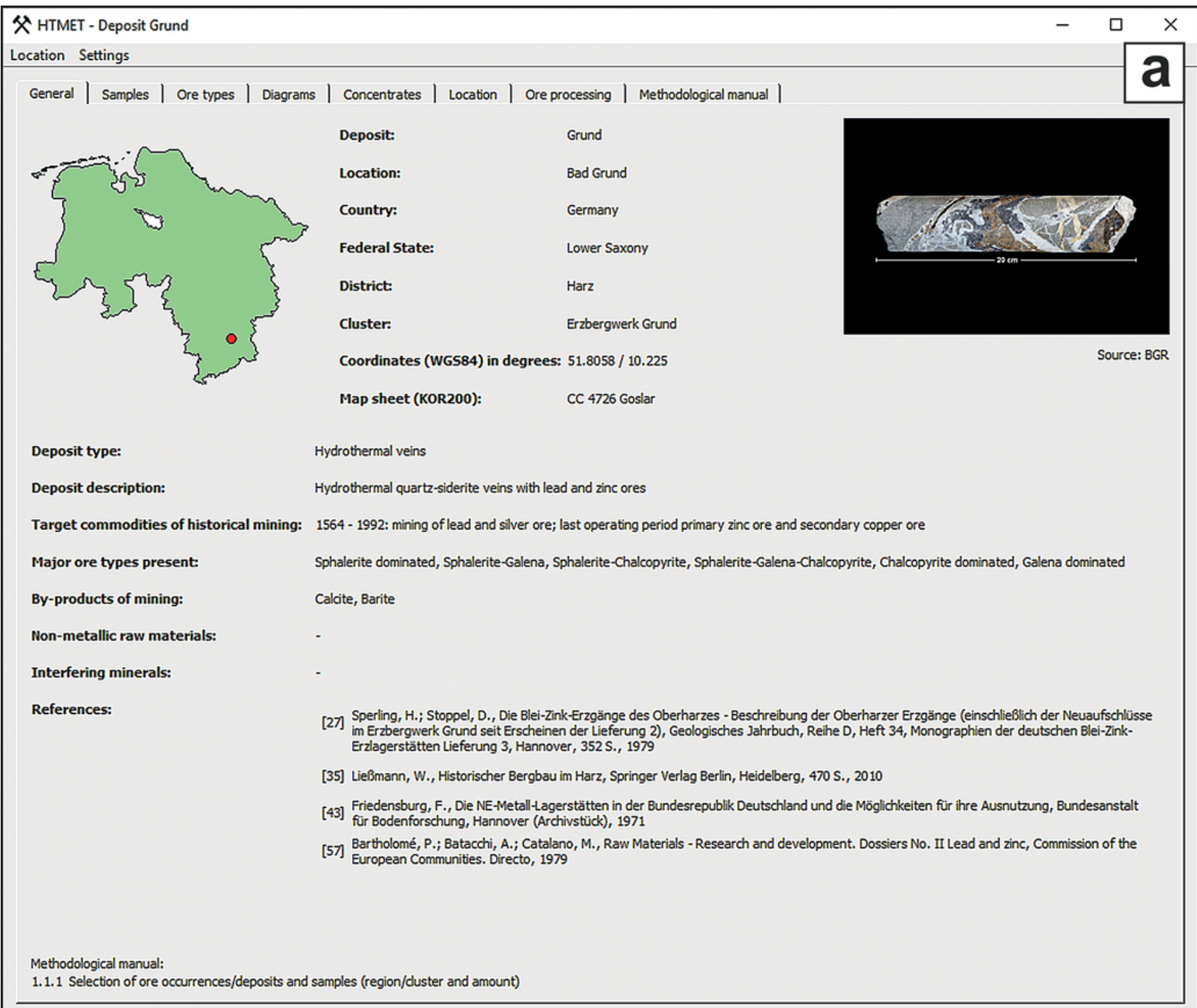

Fig. 3: Screenshots of the front end connected to the HTMET database for primary indicators of the "Grund" ore deposit (Harz district) showing (a) general data and (b) mean, median and 25/75 percentiles of mineral chemistry investigations (LA-ICP-MS/EMPA data) aggregated for sphalerite/chalcopyrite and ore types. 
(4) Summary of environmental risks/nature conservation for the cluster area (e.g. nature reserves/biotopes, effects on urban settlements, karst areas, active mine water treatment, water protection areas).

For the acquisition of tertiary indicators, mineral processing tests were conducted at the TU Clausthal on a laboratory scale using large volume bulk samples. The focus of these tests was a method development for the separation of HT metals from typical base metal ores. The results of these investigations are out of the scope of this manuscript and will be discussed in further publications.

\subsubsection{Front end of the database}

In order to conveniently visualise the database contents, a graphical user interface has been developed as a front end to the database. It is written in $\mathrm{C}++$ using the Qt framework. As well as the database itself, the structure of the front end is data driven, i.e. the design (e.g. the size of tables, the contents of lists, etc.) depends on the database contents and is dynamically generated at program start. By now the interface is realised as a Windows application, the database access is via hostname and port of the database server. For the future, a purely web-based application is to be implemented to generate access for the German State Geological Surveys (SGD), domestic industry as well as for interested private individuals, to important data compiled in the database.

Screenshots illustrating the functionality of the front end connected to the HTMET database are shown in Figs. 3 and 4 using the "Grund" ore deposit (Harz district) as an example. Fig. 3a presents the summary page of the compiled general data for the location with links to the available literature and the respective pages of the methodological manual. Fig. $3 b$ illustrates representative $\mu$-EDXRF mineral distribution maps for each ore type of the deposit. The results of the mineral chemistry investigations using LA-ICP-MS and/or EMPA are summarised for each ore type and are separately presented for either sphalerite or chalcopyrite; the embedded table lists the compiled data for all relevant ore types of the deposit. Semi-quantitative ternary (In-Ga-Ge) and quantitative XY diagrams (Ga-Ge; In-Ga) are used to classify the results of the mineral chemistry in a broader context by visualising cluster-, district- or country-based datasets (Fig. 4a). The results of bulk geochemistry analysis of concentrates (industrial concentrates and sample concentrates produced in the lab) for the "Grund" mine and pictures of the material used are shown in Fig. 4b. The database provides an export routine for data sheets for individual deposits, presenting compiled general deposit data, mineral proportions, mineral

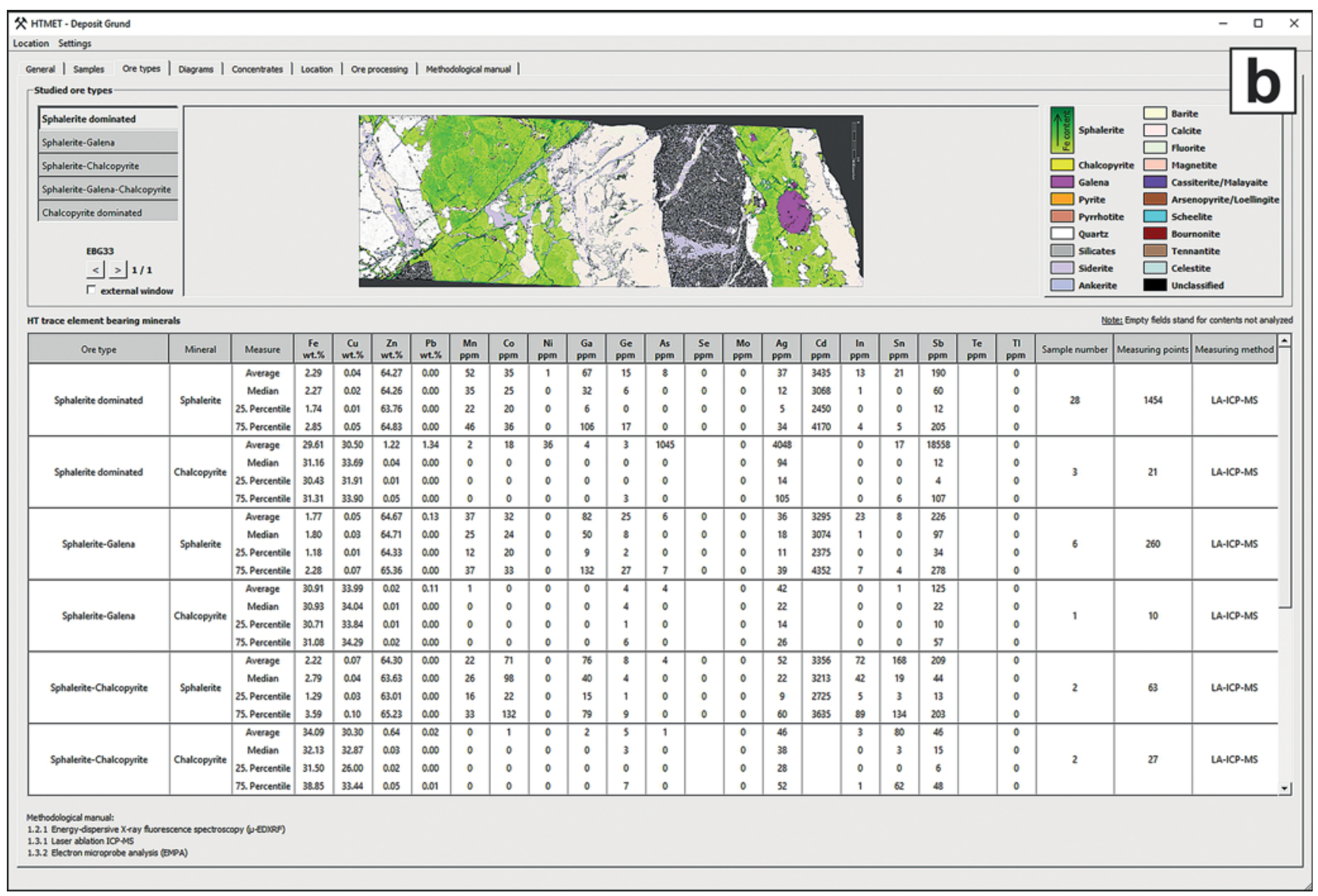

Fig. 3: cont. 


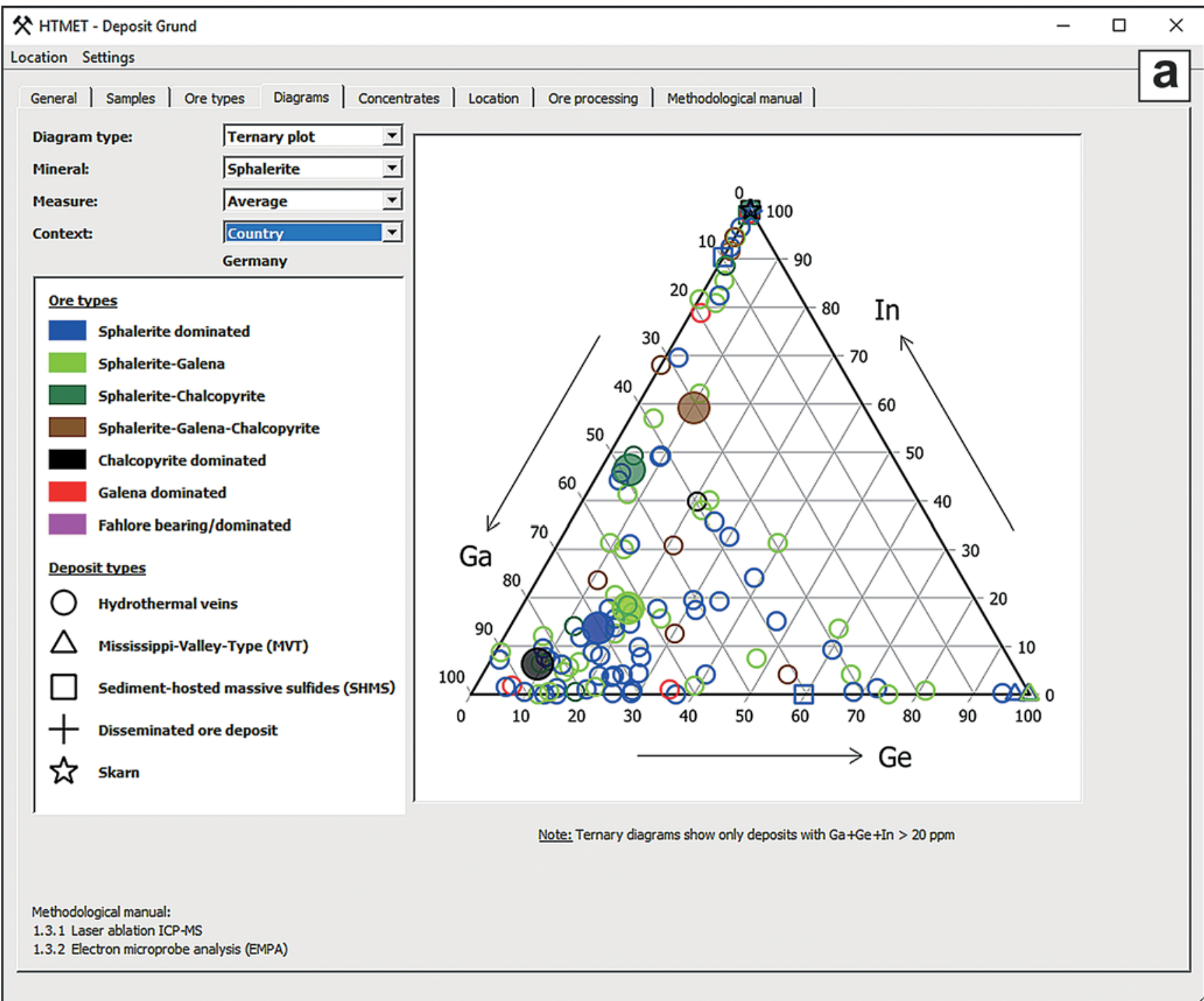

Fig. 4: Screenshots of the front end connected to the HTMET database for primary indicators of the "Grund" ore deposit (Harz district) showing (a) semi-quantitative visualisation of the mineral chemistry results (ternary diagram) in a broader context (nationwide/country) and (b) bulk ore geochemistry data for industrial and sample ore concentrates.

distribution maps, mineral chemistry, and bulk geochemistry results, as well as the semi-quantitative ternary and quantitative $\mathrm{XY}$ diagrams.

\subsubsection{Multicriterial evaluation tool}

An interactive tool was created based on the results collected for the primary indicators to evaluate the potentials of HT trace element-enriched ore types in Germany (Fig. 5). Fig. 5a shows an example for the application of the visualisation sub-tool for mineral chemistry data: From a menu for data processing the following selections are used (i) host mineral is "sphalerite", (ii) results for the HT trace elements "Germanium/Gallium/Indium" are plotted, (iii) calculated "median values" of the mineral chemistry results are given, and (iv) the selected reference level is "cluster of deposits". The data in the list of clusters were sorted in descending order using the concentrations of the element "Ge". For each cluster a colour coded segmented circle is shown that indicates the respective HT trace element concentrations from high (green) to low (red). The threshold values for the colour coding are adjustable depending on the current market situation or on the users' interests. Furthermore, filters can be applied to limit the number of shown clusters/deposits to those with the highest concentrations of a given HT element. By clicking into the table the user will be automatically directed to the multicriterial evaluation tool (Fig. 5b).

The multicriterial evaluation tool exists in a first version to estimate the raw material potentials of clusters of deposits by combining the results of the bulk geochemistry, the mineral chemistry data as well as all information on associated non-metallic raw materials and harmful minerals. The 


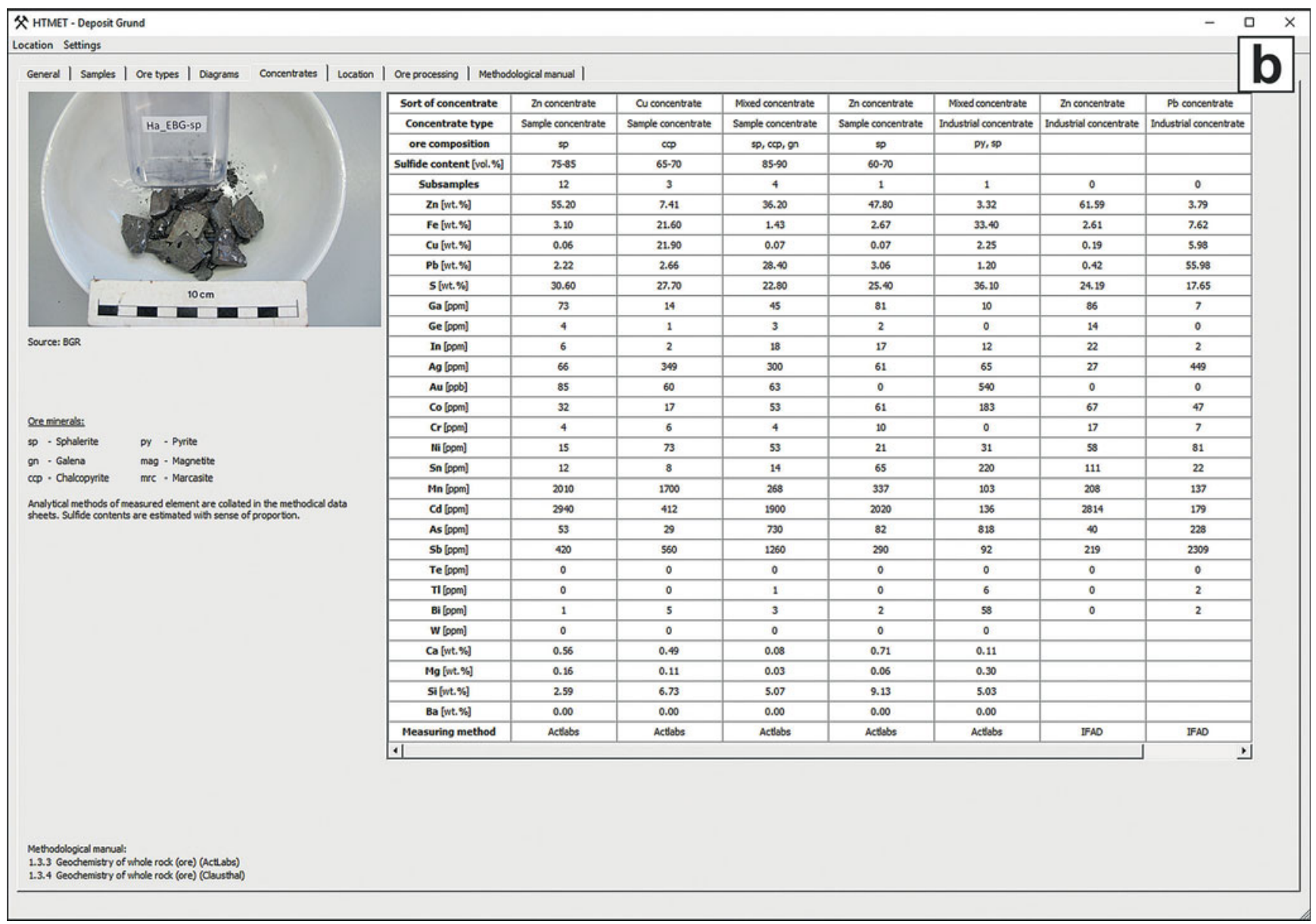

Fig. 4: cont.

user is prompted to do his selection between different deposit types, types of concentrates, and minerals that will subsequently be used for the estimation of a raw material potential for the given cluster. All bulk geochemistry results used for data processing inside the evaluation tool are normalised to the mean sulphur concentration of all concentrates in the database (by now: $23.61 \mathrm{wt} . \%$ ). This enables a comparison of chemistry data for concentrates having different sulphide contents. The threshold values used for classification of the concentrations of the HT trace elements (Ge, Ga, In) into the categories high, moderate and low (colour coded: green, yellow and red), and also their weighting factors, can be adjusted in the settings for the calculation, depending on the special demands of the individual user. The same holds true for bonus points given for associated raw materials (e.g. fluorite and barite of good quality or hard coal).

A more detailed investigation of the ore-related potentials (primary indicators) for a pre-selected cluster is carried out using the weighting factors (see above) for the selected trace elements from bulk geochemistry, mineral chemistry and the presence of probably economically important amounts of associated raw minerals. Intermediate results for the HT element concentrations are presented in the tool using the above-mentioned colour coding (representing 2, 1 and 0 point, respectively, for calculation of a final score). The scored points characterise the HT potential of the cluster and are shown compared to a maximum possible score for the user settings (Fig. 5b).

In case that exploration and mining activities are planned for target regions, not only the known metal concentrations in ore types and possible amounts of resources form important parameters for pre-selection of possible study sites, infrastructural and environmental aspects also have a huge effect on the economic viability of mining operations. The overall degree of development of the infrastructure, length and nature of possible transport routes for mining-related materials to a mine site or from a mine to the nearest processing plant as well as the availability of water, energy and skilled workers, are very important mine site-related factors. If environmentally sensitive areas, competing use of mining sites (e.g. tourism, recreation areas) or numerous legal requirements are present, even districts with an estimated high potential for the primary indicators, or substantial parts of them, have to be excluded from exploration projects. These infrastructural and environmental issues (secondary indica- 


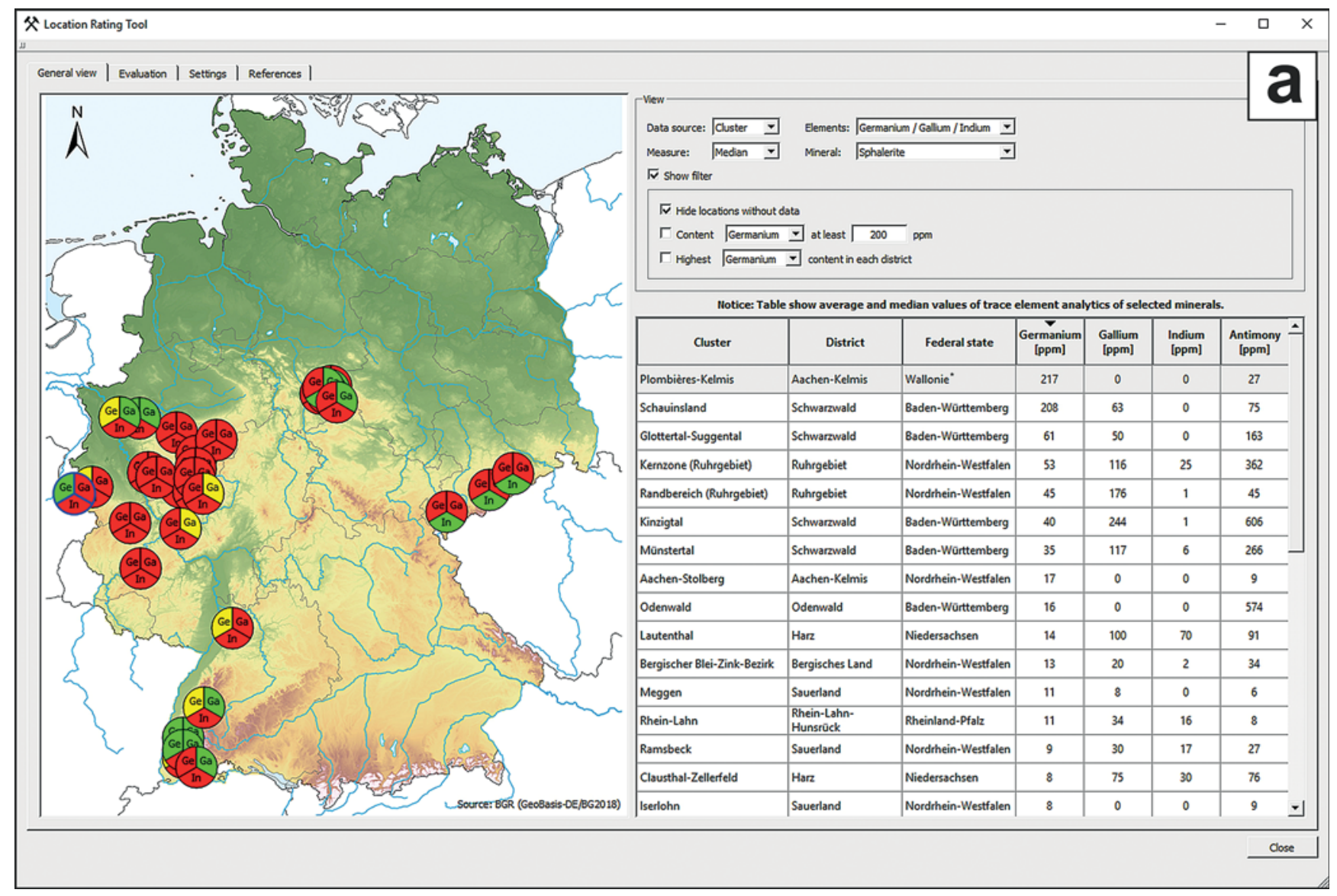

Fig. 5: First version of the evaluation tools connected to the HTMET database. (a) Visualisation of mineral chemistry results (median) for sphalerite, data is grouped for clusters of deposits (segmented circles represent high (green) to low (red) HT trace element concentrations); *all data from Belgium (BE) are added for scientific comparison only. (b) Multicriterial evaluation tool combining the results of bulk geochemistry, mineral chemistry and the presence of associated raw materials and harmful minerals in the cluster "Grund ore mine" and furthermore illustrating the evaluation of secondary indicators.

tors) are also included in the database. They are summarised and evaluated by means of a traffic light system in the multicriterial evaluation tool (Fig. 5b).

\subsection{Genetic deposit types}

The present study focuses on the critical raw material potential of important German mining districts and clusters. A starting hypothesis for the advanced scientific data interpretation is a clear dependency of the HT element "specialisation" of given ores on a genetic deposit type (SchwarzSchampera \& Herzig 2002; Cook et al. 2009; Frenzel et al. 2016) and also on geological features of the respective sampled locations. Fig. 6 illustrates four exemplary false colour mineral distribution maps of samples, which are all assigned to the "sphalerite-dominated" ore type, but derive from different genetic deposit types: (a) Ore samples from the SHMS deposit "Rammelsberg" (Harz) are commonly characterised by banded iron-rich sphalerite, associated pyrite and chalcopyrite (Fig. 6a). This type of deposit forms by uprising hydrothermal fluids in a water reservoir at a temperature be- tween $180-450{ }^{\circ} \mathrm{C}$ (Nielsen 1985). The precipitated ores are deposited on the seafloor simultaneous to the sedimentary host rocks and form characteristic stratiform massive sulphide layers. (b) The ore sample from the skarn deposit "Berggießhübel" (Erzgebirge) contains iron-rich sphalerite as well, but the latter is associated with magnetite and garnet (Fig. 6b). Skarn deposits form due to high-temperature (210-650 ${ }^{\circ} \mathrm{C}$; Kwak 2007) metasomatic replacement processes (often in carbonate rocks) usually spatially related to magmatic intrusions and are mineralogically complex. (c) Sphalerite in samples from hydrothermal vein deposits can show a variety of textures and iron concentrations, is commonly associated with various other sulphides and gangue minerals and often comprises numerous brecciated host rock fragments (Fig. 6c). The varying iron concentration in sphalerite is indicated in the mineral distribution maps highlighting growth zoning structures in the mineral. Hydrothermal vein deposits form by ore precipitation from uprising mostly low- to moderate-temperature, highly-saline and metal-bearing hydrothermal fluids and show a variety of different mineral paragenesis depending on fluid characteristics and metal sources. (d) Samples from Mississippi-Valley-Type deposits 


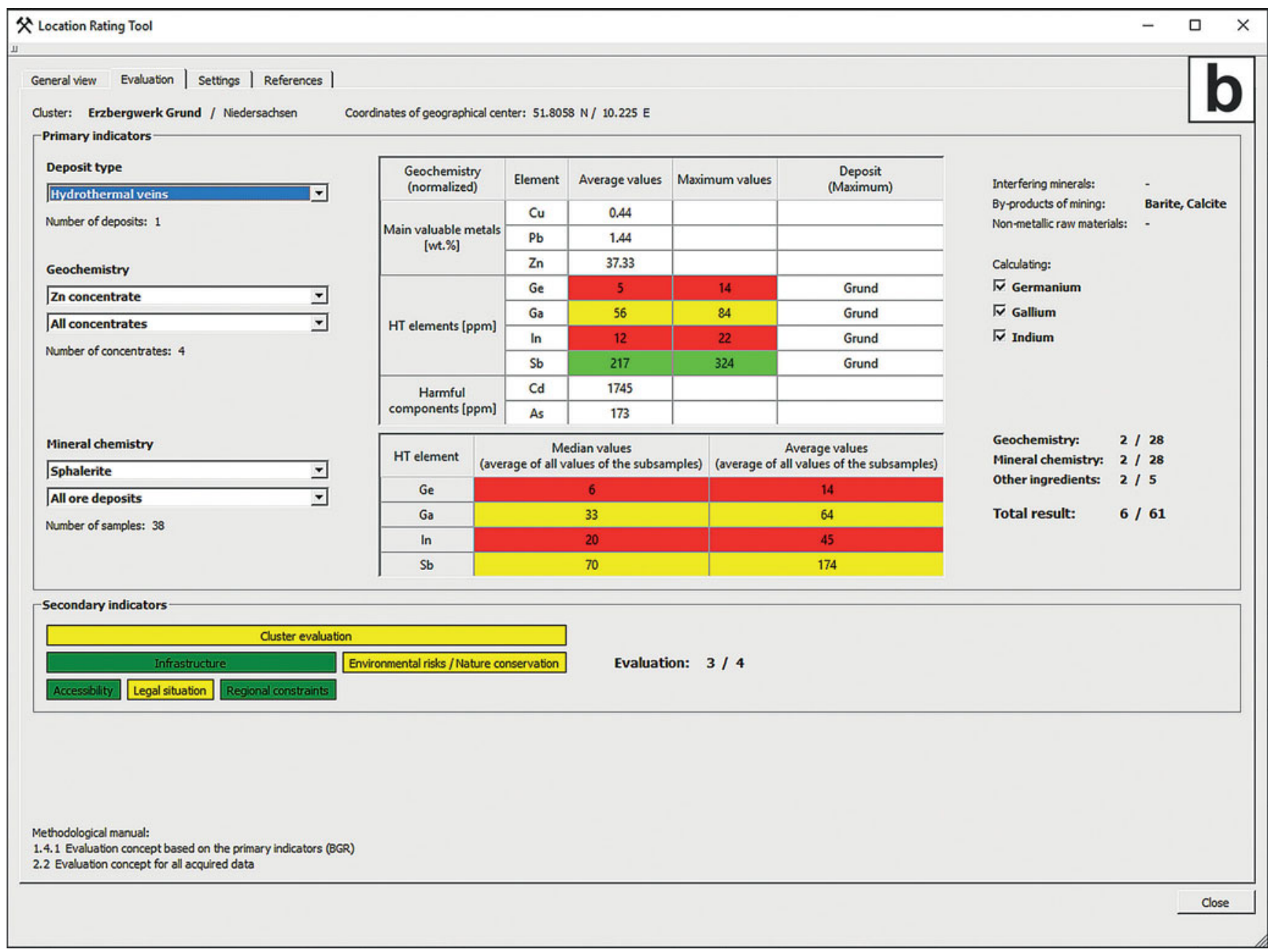

Fig. 5: cont.

are characterised by typical colloform sphalerite/wurtzite ("Schalenblende") with varying iron concentrations, often associated with massive iron sulphides and galena (Fig. 6d). These deposits form by low temperature and highly-saline fluids reacting with carbonate rocks such as limestone, marl or dolomite or hosted in cavities. (e) Mineral distribution maps of samples from disseminated base-metal ore deposits are not shown due to the commonly very fine-grained sample material. Disseminated ore deposits, such as the sandstone-hosted lead-zinc deposits of "Maubach" and "Mechernich" (both Eifel), are considered to have formed epigenetically from circulating hydrothermal fluids in pre-existing sandstone.

\subsection{Trace element distribution in Germany's base metal ore deposits}

The obtained comprehensive mineral chemistry data (number of LA-ICP-MS/EMPA spots: sphalerite 16,471; chalcopyrite 1,465$)$ provides a unique basis to study the principles in the HT trace element concentration and specialisation of sulphides from a large segment of the Variscan Orogen, the important German base metal mining districts. The results of the mineral chemistry analysis for the HT elements Ga, Ge and $\mathrm{In}$ in sphalerite are presented as box plot diagrams in Fig. 7. They are grouped according to the genetic deposit types as defined by previous studies and to the ore districts. The box plot diagrams provide an overview of the distribution of trace elements in the sphalerite ores of the German base metal mining districts. For further exploration activities, the results have to be considered in greater detail on a cluster and single deposit scale, due to the observed variability within the districts.

Despite the well-known high natural variability in the distribution of trace elements in natural samples, it can be deduced from the data that sphalerite from all hydrothermal vein deposits is characterised by moderate and more homogenous Ga concentrations (median 6-81 ppm; Fig. 7a) compared to MVT, SHMS, skarn and DISSEM deposits (all median values $<8$ ppm; Fig. 7b). The presence of strongly elevated Ge concentrations in sphalerite of hydrothermal vein deposits in Germany was found to be restricted to several deposits in the Schwarzwald and the Ruhrgebiet districts 


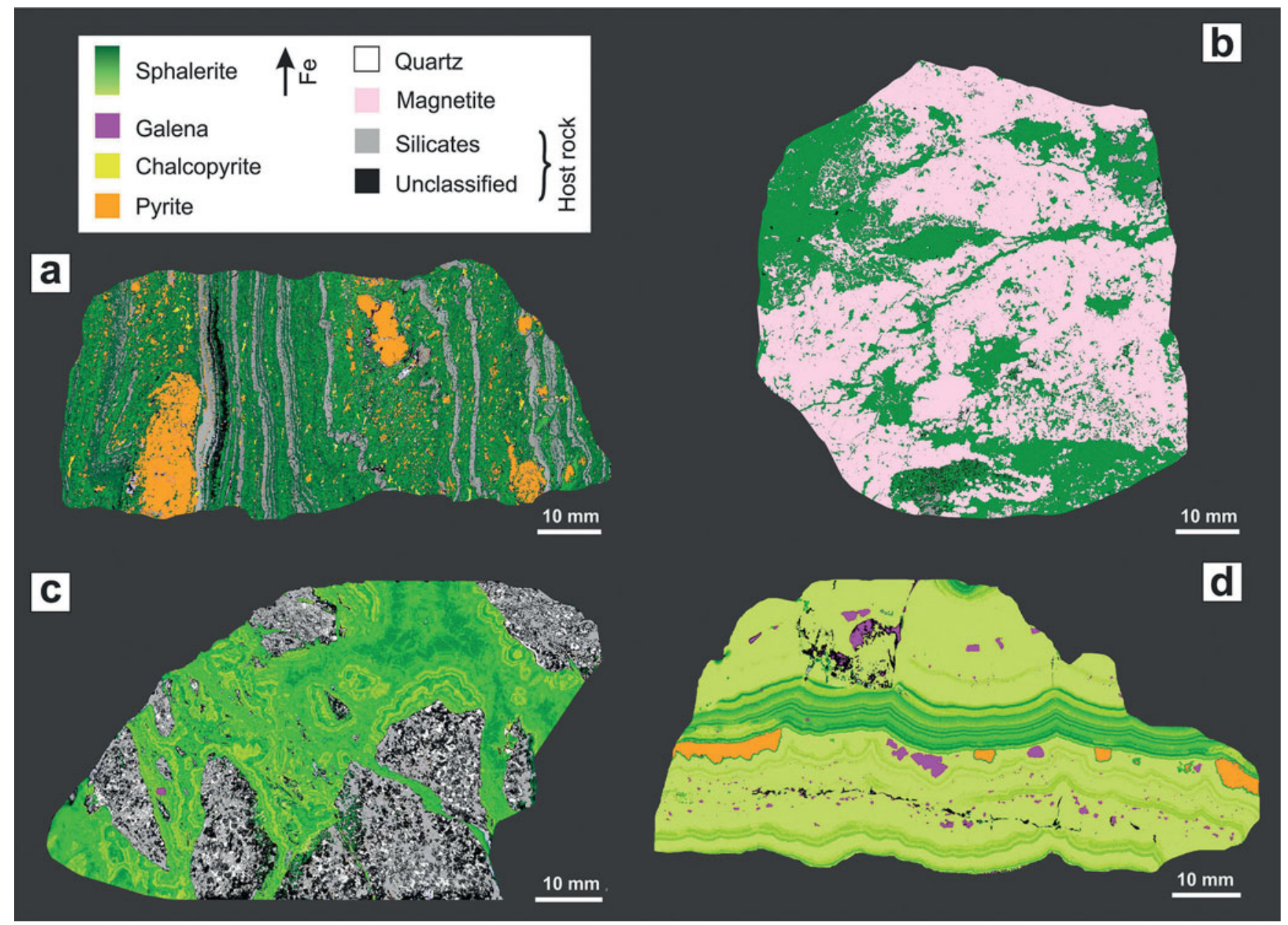

Fig. 6: False colour mineral distribution maps ( $\mu$-EDXRF) showing "sphalerite-dominated" ore samples from different genetic deposit types: (a) SHMS deposit "Rammelsberg" (Harz); (b) skarn deposit "Berggießhübel” (Erzgebirge); (c) hydrothermal vein deposit "Schauinsland" (Schwarzwald); (d) MVT deposit "Altenberg" (Aachen-Kelmis).

(median 55-73 ppm; Fig. 7c). Besides that, Ge is characteristically enriched in colloform sphalerite/wurtzite ("Schalenblende") from MVT deposits in the Aachen-Kelmis and Odenwald districts (median 29-147 ppm; Fig. 7d). However, crystalline sphalerite from the MVT deposit Wiesloch (Odenwald; not shown in Fig. 7) and sphalerite from two deposits from the Erzgebirge also attributed to the MVT-type (e.g. Hermsdorf; Schwerdtfeger 2000) is rather poor in all HT trace elements. Sphalerite of the investigated SHMS and skarn deposits is typically depleted in Ge except for the SHMS deposit "Meggen" in the Sauerland district (median 11 ppm; Fig. 7d). In contrast to Ga and Ge, the HT trace element In could not be detected in significant concentrations in sphalerite of hydrothermal vein deposits in Germany (median $<4$ ppm; Fig. 7e), except for elevated In concentrations in some vein types of deposits in the Erzgebirge district (median 33 ppm; Fig. 7e). However, single laser spots and EMPA analysis reveal a very local enrichment of up to $6,500 \mathrm{ppm}$ In in single sphalerite grains of several hydrothermal vein deposits. The highest enrichment of In was found in the Ram- melsberg cluster (SHMS; median 75 ppm; Fig. 7f) and skarn deposits of the Erzgebirge (median 14-119 ppm; Fig. 7f).

As mentioned above, investigations on the mineral chemistry of chalcopyrite and geochemical analysis of bulk rock samples were conducted and form a significant part of the database HTMET. The main results are briefly summarised in the following paragraph.

Compared to sphalerite, chalcopyrite appears less frequently in many of the investigated deposits. In most samples, only a few chalcopyrite grains were suitable for analysis (scarcity, grain sizes). Chalcopyrite of the Schwarzwald, Rhein-Lahn-Hunsrück and the Erzgebirge districts contain up to hundreds of ppm of In. Germanium was found in noteworthy concentrations (median up to $142 \mathrm{ppm}$ ) in the Schwarzwald and the Ruhrgebiet districts. In contrast to that, $\mathrm{Ga}$ is not significantly enriched in chalcopyrite of the German base metal ore districts.

Geochemical bulk ore analyses were conducted on 101 industrial and lab sample concentrates of 59 deposits to cross-check the mineral chemistry data. Despite variations in the proportions of sulphide phases in the investigated sample 


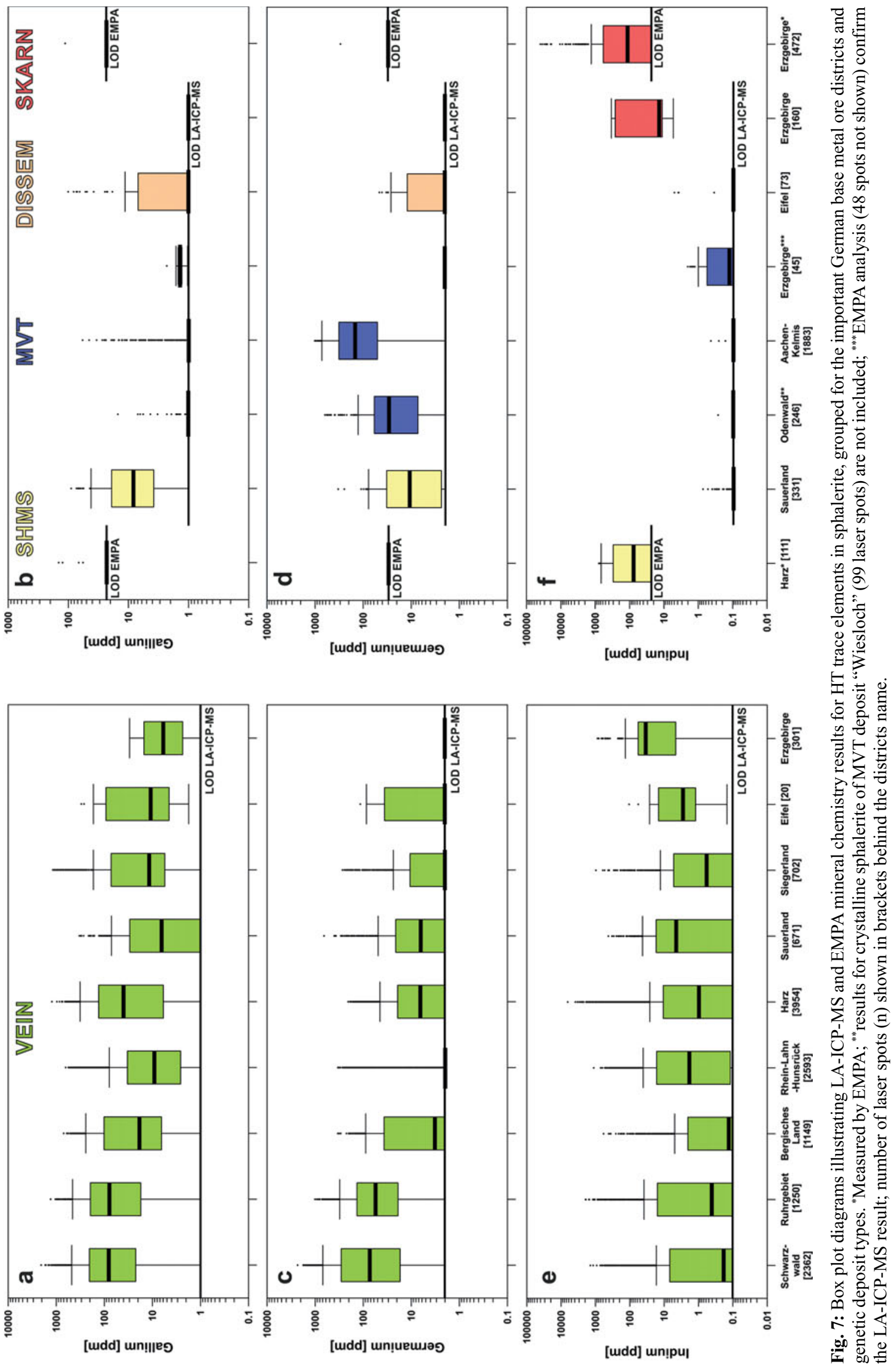


material, the results allow information on the trace element concentrations in larger volumes of ore material. In general, the results confirm the mineral chemistry data for sphalerite and chalcopyrite, e.g. the moderate Ga concentrations in hydrothermal vein deposits, the elevated Ge concentrations in MVT deposits from the Aachen-Kelmis district, the enrichment of Ge in sulphides from hydrothermal veins of the Schwarzwald and Ruhrgebiet districts and the enrichment in In in sulphides from skarn (Erzgebirge) and SHMS (Rammelsberg) deposits. Contrary to the mineral chemistry data, the geochemical data indicates occasionally elevated $\mathrm{Ge}$ concentrations in sulphides of hydrothermal vein deposits from the Bergisches Land and the Harz districts (up to $42 \mathrm{ppm}$ ) as well as elevated In concentrations in concentrates from a few hydrothermal vein deposits (up to $361 \mathrm{ppm}$ ).

\subsection{Evaluation of HT trace element potentials}

Starting from an evaluation of the mineral chemistry data and all results from the study of mineral concentrates, differences in the trace element specialisations, concentration, and potentials of the various investigated German base metal mining districts became apparent (Table 3, Figs. 5a, 7). In the paragraphs below, these differences will be discussed for each of the HT trace elements separately.

\section{Gallium}

When comparing base metal deposits, the HT trace element $\mathrm{Ga}$ is most commonly incorporated in sphalerite from hydrothermal vein mineralisations. In this study elevated contents with respect to the average crustal abundance (19 ppm; Butcher \& Brown 2013) were especially found in sphalerite of the Schwarzwald, Ruhrgebiet and Harz districts (mean 87-160 ppm; median 41-81 ppm; Fig. 7a). According to Cook et al. (2009), Frenzel et al. (2016) and others, Ga is preferentially enriched in deposits formed at lower temperatures. This fits well to the fact that the temperatures of metalbearing fluids that formed the hydrothermal vein deposits in the above districts are described to be rather low $\left(<200{ }^{\circ} \mathrm{C}\right.$; e.g. Möller 1987; Baatartsogt et al. 2007; Henning et al. 2019) compared to the estimated formation temperatures of skarn $\left(210-650^{\circ} \mathrm{C}\right.$; Kwak 2007) and SHMS deposits (180$450{ }^{\circ} \mathrm{C}$; Nielsen 1985 ).

However, not only the temperature seems to play a significant role in the enrichment of metals, but also the host rocks that act as potential metal sources. A probable source for the elevated Ga concentrations in hydrothermal vein deposits is the interaction of highly saline fluids with the widespread clastic rocks that typically host the hydrothermal vein deposits. Often packages of sedimentary rocks are characterised by elevated proportions of aluminosilicate minerals such as feldspar and mica that contain Ga in trace concentrations (e.g. Schirmer et al. 2017), due to similar properties of $\mathrm{Ga}^{3+}$ and $\mathrm{Al}^{3+}$ in charge and ionic radius. As a consequence of the intense interaction of the hydrothermal fluids with the adjacent host rock, $\mathrm{Ga}$ is released from these minerals into the hydrothermal fluids (Timofeev \& Williams-Jones 2014;
Sahlström et al. 2017). Such a process is also indicated by the presence of secondary clay minerals such as kaolinite or illite, which are commonly found close to the hydrothermal vein mineralisation (Buschendorf et al. 1951; Werner et al. 2002).

An obvious lack of the above mentioned Ga source also explains the Ga poor sphalerite from MVT and DISSEM deposits in Germany. These deposits were formed by similar high-salinity and low temperature hydrothermal fluids (basinal brines; MVT: $75-200^{\circ} \mathrm{C}$, Paradis et al. 2007; DISSEM: $100-160^{\circ} \mathrm{C}$, Laznicka 2010 ) as the hydrothermal veins, but the mineralisation is localised in feldspar and mica poorer environments (carbonate rocks, MVT); sandstones and conglomerates, DISSEM). Typically, Ga contents in MVT deposits are rather low (e.g. mean 2.2 ppm; Goffin et al. 2015), however, MVT deposits containing $50 \mathrm{ppm} \mathrm{Ga}$ on average are also described in the literature (Moskalyk 2003).

Assuming a successful establishment of an adequate resource basis and sufficiently high metal prices on the world market, there might be a potential for the extraction of $\mathrm{Ga}$ as a by-product following mining of the major metals $(\mathrm{Zn}, \mathrm{Pb}, \mathrm{Cu})$ and gangue minerals (e.g. fluorite, barite) in the Schwarzwald, Ruhrgebiet and Harz districts in the future. However, Ga is extracted solely as a by-product of aluminium production of bauxite (average contents $50 \mathrm{ppm}$ ) at present (Butcher \& Brown 2013).

\section{Germanium}

The average abundance of $\mathrm{Ge}$ in the continental crust is $1.6 \mathrm{ppm}$ (Taylor \& McLennan 1985). Considering all studied base metal mineralisations in Germany, Ge is especially enriched in collomorphic sphalerite of MVT deposits in the Aachen-Kelmis and Odenwald districts (mean 62-210 ppm; median 29-147 ppm; Fig. 7d). This result is in accordance with investigations conducted by Pfaff et al. (2011; median 37 ppm Ge) and Goffin et al. (2015; mean 302 ppm Ge) for the "Wiesloch" mine in the Odenwald district and for several Belgian MVT deposits. However, sphalerite from several hydrothermal vein deposits of the Ruhrgebiet and the Schwarzwald districts also contain significantly elevated $\mathrm{Ge}$ contents (median 55-73 ppm; Fig. 7c). Germanium enrichment in hydrothermal ore from the latter district ("Schauinsland" mine) was also reported by Werner et al. (2002).

Similar to $\mathrm{Ga}$, $\mathrm{Ge}$ is also expected to be preferentially bound to deposits that have formed at lower temperatures (Cook et al. 2009; Frenzel et al. 2016). This statement fits well to the elevated Ge values observed in the low-temperature MVT, low-temperature hydrothermal vein deposits and, also, to the low Ge values in the investigated high-temperature skarn and SHMS deposits (Table 3; Figs. 5a, 7). However, low-temperature hydrothermal vein deposits do not necessarily contain sphalerite with elevated $\mathrm{Ge}$ concentrations. Vein sphalerite with low Ge concentration is also commonly present (e.g. in the Bergisches Land and Rhein-Lahn-Hunsrück districts). On the other hand, sphalerite from VHMS and SEDEX deposits (up to 100 ppm Ge; Kelley et al. 2004; Höll et al. 2007), as well as "Tsumeb-type" polymetallic deposits containing Ge (up to $427 \mathrm{ppm}$ ), are also described in the literature (Emslie \& Beukes 1981). 
Table 3: HT raw material potential of historic German base metal mining districts and deposit types as estimated by the evaluation of the primary, ore chemistry-related indicators.

\begin{tabular}{|c|c|c|c|c|}
\hline Historical mining district & Germanium & Gallium & Indium & Genetic deposit type \\
\hline \multirow[t]{2}{*}{ Harz } & no & increased & no & VEIN \\
\hline & no & no & increased & SHMS \\
\hline Ruhrgebiet & increased & increased & no & VEIN \\
\hline \multirow[t]{2}{*}{ Sauerland } & no & low & no & VEIN \\
\hline & low & low & no & SHMS \\
\hline Bergisches Land & no & low & no & VEIN \\
\hline Siegerland & no & low & no & VEIN \\
\hline Aachen (DE)-Kelmis (BE) & increased & no & no & MVT \\
\hline \multirow[t]{2}{*}{ Eifel } & no & no & no & DISSEM \\
\hline & no & low & no & VEIN \\
\hline Rhein-Lahn-Hunsrück & no & low & no & VEIN \\
\hline Odenwald & increased & no & no & MVT \\
\hline Schwarzwald & increased & increased & no & VEIN \\
\hline \multirow[t]{3}{*}{ Erzgebirge } & no & no & increased & SKARN \\
\hline & no & no & no & MVT \\
\hline & no & low & increased & VEIN \\
\hline
\end{tabular}

This means that the degree of Ge enrichment in base metal deposits is not only a function of the temperature of formation of the mineralisation. One important aspect is the biophile affinity of $\mathrm{Ge}$, resulting in its close association with organic matter (e.g. lignite, hard coal, bitumen, carbonaceous sediments; Bernstein 1985; Höll et al. 2007. The mobilisation of $\mathrm{Ge}$ from organic matter-rich sedimentary rocks by hydrothermal fluids is assumed to be an important process especially in MVT and "Tsumeb-type" deposit formation (Melcher et al. 2006; Saini-Eidukat et al. 2016). These authors suggested that the occurrence of larger amounts of organic matter plays an important role in the transport and enrichment of Ge in sphalerite of base metal deposits.

As $\mathrm{Ge}$ is, in contrast to $\mathrm{Ga}$, not enriched in sulphides of all hydrothermal vein districts, a ubiquitously available source like its release as a result of silicate weathering (similar properties of $\mathrm{Ge}^{4+}$ and $\mathrm{Si}^{4+}$ ), does not seem likely for these local $\mathrm{Ge}$ enrichments. Here, the associated occurrence of organic matter (e.g. hard coal [Ruhrgebiet]) might have played an important role on the strong Ge enrichment in the adjacent base metal mineralisation. The incorporation and transport mechanisms, possible HT metal sources and the required physicochemical fluid properties that led to the enrichment of HT trace elements in hydrothermal vein deposits of the Schwarzwald and Ruhrgebiet districts are a focus of detailed scientific studies (Henning et al. 2018, 2019).

The moderate to elevated Ge concentrations in sphalerite from the Schwarzwald, Ruhrgebiet, Aachen-Kelmis and Odenwald districts provide an increased potential for the extraction of $\mathrm{Ge}$ as a by-product related to base metal and gangue mineral mining, as the prices for $\mathrm{Ge}$ are much higher compared to In and Ga. Furthermore, Ge is already processed from zinc ore concentrates besides its extraction from coal ashes (Melcher \& Buchholz 2013).

\section{Indium}

The continental crust contains about $0.05 \mathrm{ppm}$ of In on average (Taylor \& McLennan 1985). According to this study sphalerite from vein and skarn deposits in the Erzgebirge district (median 33-109 ppm; Figs. 7d, f) and from the SHMS deposit "Rammelsberg" in the Harz district (median 75 ppm; Fig. 7f) shows a strong enrichment in In; this fits well to literature data (Mehner 1993; Schwarz-Schampera \& Herzig 2002; Seifert \& Sandmann 2006). In contrast to Ge and $\mathrm{Ga}$, In is expected to be enriched in deposits that formed at higher temperatures (Schwarz-Schampera \& Herzig 2002). This statement supports the In enrichment in the skarn deposits and the SHMS deposit "Rammelsberg" and, on the other hand, the lack of In in MVT and DISSEM deposits as observed in this study.

Except for the hydrothermal veins in the Erzgebirge district (median 33 ppm; Fig. 7e), the base metal veins of all other vein districts in Germany are characterised by overall low (all median values $<4$ ppm; Fig. 7 e), but, on a local scale, occasionally highly variable In concentrations. Although most of these veins are expected to have formed at lower temperatures $\left(<250{ }^{\circ} \mathrm{C}\right)$, several zones with up to $6,500 \mathrm{ppm}$ of In in sphalerite grains were found by LA-ICPMS; here, In enrichment in narrow growth zoning related bands is confirmed by EMPA element maps (Henning et al. 2019). These elevated In contents are also confirmed by bulk 
ore analyses from ores of hydrothermal vein deposits that contain up to $360 \mathrm{ppm}$ of In.

Indium is commonly enriched in the late stage, high-temperature step of massive sulphide, vein type and replacement ore body formations that are related to volcanic and intrusive magmatic environments and generally associated with elevated contents of $\mathrm{Cu}$ or $\mathrm{Cu}$-rich minerals (Schwarz-Schampera \& Herzig 2002). This idea is suitable for the explanation of elevated In concentrations in sphalerite of the complex SHMS ("Rammelsberg") and skarn (Erzgebirge) mineralisations. However, it does not explain the partly elevated In concentrations in sphalerite of the low to moderate temperature hydrothermal vein deposits that formed from migrating basinal brines and meteoric fluids. In these deposits, fluid/ rock interaction and transport mechanisms, as well as the recrystallisation and replacement processes of In-hosting sphalerite may have played a significant role in the enrichment of In and especially the contribution of higher temperature fluid pulses needs further scientific investigation.

Indium is extracted as a by-product from sulphidic base metal ores using residues from $\mathrm{Zn}$ and $\mathrm{Cu}$ extraction. Taking into account the economically relevant In contents of worldwide zinc ores and concentrates deriving from VHMS and SHMS deposits (20-200 ppm; Schwarz-Schampera 2013), it is obvious that there is a potential for the extraction of the HT trace element In as a by-product from some German base metal ores. The "Rammelsberg" mine produced In in the past and the area around the mine just recently formed the focus of a new exploration campaign (Mehner 1993; Eichhorn 2011). Furthermore, there are also ongoing exploration activities in the Erzgebirge district, which hosts some interesting targets for In extraction (Saxore 2015).

In general, extraction of HT trace elements can only be economic as a by-product of the mining of major metals (e.g. $\mathrm{Pb}, \mathrm{Zn}, \mathrm{Cu}, \mathrm{Sn}$ ) and associated raw materials (e.g. calcite, fluorite, barite). Furthermore, the knowledge on the proportions of the base metals in the ore and the remaining ore resources in the old mining districts is indispensable for a final evaluation of possible exploration activities. In some districts, important mines were closed due to strongly increased costs for mine dewatering, rapid falls in base and precious metal prices or unsolvable problems with the beneficiation of important ore types (e.g. vein deposits of the Harz and Schwarzwald districts, skarn deposits of the Erzgebirge district); consequently, significant quantities of raw materials are occasionally still present in such deposits. The mineralogical and geochemical data in the HTMET database, as well as the first approach on evaluating the collected data for the primary indicators, form a fundamental basis for future studies and exploration work. The database can be expanded for further ore types, commodities and additional ore districts. The secondary indicators present important infrastructural data for possible exploration activities, but also exclusion criteria for mining activities in ecologically sensitive areas.

\section{Conclusions}

The systematic mineralogical and geochemical investigations represent a fundamental basis for planning of exploration activities in the old German base metal mining districts. The resulting HTMET raw material database provides a systematic overview of HT trace element potentials in these ore districts. Base metal ores of some mining districts indicate a potential for further exploration activities under special consideration of the HT metals. Although trace element mining alone will probably never be economic (except for some precious metals), these metals can be processed as by-products to major metals and associated raw materials such as fluorite, barite or calcite, to improve the profitability of a mining project.

The present study proves sphalerite as the main carrier of the HT trace elements Ge, Ga and In in the investigated sulphide mineralisations. The assumed dependency of HT trace element specialisation and concentration on the genetic ore deposit type is mostly confirmed by our data, but HT trace element inventory also forms a function of the district- and location-related variable geological environments such as source-rock and fluid composition or organic content of rock:

(1) Gallium is primarily enriched in sphalerite from hydrothermal base metal vein deposits due to intense fluid/rock interaction of the mineralisation-related basinal brines with adjacent feldspar- and mica-bearing source-rocks.

(2) Germanium is especially enriched in sphalerite of mineralised bodies that are somehow spatially related to significant volumes of organic matter or carbonaceous sediments, such as hard coal in the Ruhrgebiet or bituminous substance in MVT environments. Germanium-rich sulphides occur partly independent of the genetic deposit type.

(3) Indium is commonly enriched in deposits that formed at higher temperatures (e.g. SHMS, skarn type deposits), however, the partly elevated In concentrations in distinct zones of sphalerite from low to moderate temperature hydrothermal vein deposits remain unexplained. Higher-temperature fluid pulses, recrystallisation processes of sulphides and transport mechanisms need to be investigated.

The new database and first approach on an attached multicriterial evaluation are useful tools to illustrate a systematic overview of the HT trace element potentials of important German base metal districts as a basis for future exploration work. Further data can be easily added and an expansion of the HTMET database is possible for further regions (EU/ worldwide), deposit types (e.g. copper shale) and elements (e.g. rare earth elements). To be fully useful as an exploration tool, data on proportions and amounts of major metals and on the quality of associated raw materials have to be added to the database and the evaluation tool has to be further developed. Whether the domestic metal ores can actually be economically produced in the future depends primarily on developments in world market prices. A restart of metal mining in Germany requires mining licensing procedures and substantial investments in new mining equipment and processing plants. 
The mineralogical and geochemical data on trace element concentrations in sulphide minerals from different genetic deposit types obtained during this research project is under further use for various studies on distribution, transport and incorporation mechanisms of these critical HT trace elements (Franke et al. 2018; Henning et al. 2018, 2019).

\section{Acknowledgements}

The results of this study contribute to the BGR project RoStraMet and the $\mathrm{r}^{4}$-research project HTMET funded by the German Federal Ministry of Education and Research (BMBF). The authors would like to thank the affiliated and associated partners of the joint research project for providing sample material and for the exchange of ideas. We are grateful to Wolfgang Werner and another, anonymous reviewer for their helpful comments, which have significantly improved the manuscript. D. Henry and M. Frey are thanked for sample preparation. Special thanks go to E. Kallmeier, A. Hellmann, K. Kuhn, and all geologists from the German State Geological Surveys (SGD) for the continuous support of project work. D. Rammlmair, W. Nikonow, D. Göricke, S. Goldmann, C. Wöhrl and H.-E. Gäbler are thanked for analytical support on the $\mu$-EDXRF, EMPA and LA-ICP-MS investigations.

\section{References}

Baatartsogt, B., Schwinn, G., Wagner, T., Taubald, H., Beitter, T. \& Markl, G. (2007): Contrasting paleofluid systems in the continental basement: A fluid inclusion and stable isotope study of hydrothermal vein mineralization, Schwarzwald district, Germany.-Geofluids, 7: 123-147; DOI: 10.1111/j.1468-8123.2007. 00169.x

Belissont, R., Boiron, M.-C., Luais, B. \& Cathelineau, M. (2014): LA-ICP-MS analyses of minor and trace elements and bulk Ge isotopes in zoned Ge-rich sphalerites from the Noailhac-SaintSalvy deposit (France): Insights into incorporation mechanisms and ore deposition processes. - Geochim. Cosmochim. Acta, 126: 518-540; DOI: 10.1016/j.gca.2013.10.052

Bernstein, R.L. (1985): Germanium geochemistry and mineralogy. - Geochim. Cosmochim. Acta, 49: 2409-2422; DOI: 10.1016/0016-7037(85)90241-8

Buschendorf, F., Hesemann, J., Pilger, A. \& Richter, M. (1951): Monographien der Deutschen Blei-Zink-Erzlagerstätten: Die Blei-Zink-Erzvorkommen des Ruhrgebietes und seiner Umrandung: A: Übersicht über die Blei-Zink-Erzvorkommen des Ruhrgebietes und seiner Umrandung. - Beih. Geol. Jb., 3.

Butcher, T. \& Brown, T. (2013): Gallium. - In: Gunn, G. (ed.): Critical metals handbook: 150-176; Oxford (Wiley).

Cook, N.J., Ciobanu, C.L., Pring, A., Skinner, W., Shimizu, M., Danyushevsky, L., Saini-Eidukat, B. \& Melcher, F. (2009): Trace and minor elements in sphalerite: A LA-ICPMS study.Geochim. Cosmochim. Acta, 73: 4761-4791; DOI: 10.1016/j. gca.2009.05.045

Danyushevsky, L., Robinson, P., Gilbert, S., Norman, M., Large, R., McGoldrick, P. \& Shelley, M. (2011): Routine quantitative multi-element analysis of sulphide minerals by laser ablation
ICP-MS: Standard development and consideration of matrix effects. - Geochemistry: Exploration, Environment, Analysis, 11: 51-60; DOI: 10.1144/1467-7873/09-244

Eichhorn, P. (2011): Suche und Erkundung am Rammelsberg und in seiner Umgebung: 166 p.; Goslar (Förderverein Rammelsberger Bergbaumuseum Goslar/Harz e.V.).

Emslie, D.P. \& Beukes, G.J. (1981): Minor- and trace-element distribution in sphalerite and galena from the Otavi Mountainland, South West Africa. - Ann. Geol. Surv. S-Afr., 15: 11-28.

Flude, S., Haschke, M. \& Storey, M. (2017): Application of benchtop micro-XRF to geological materials. - Mineral. Mag., 81 (4): 923-948; DOI: 10.1180/minmag.2016.080.150

Franke, H., Graupner, T., Sindern, S., Henning, S. \& Pursche, K. (2018): Coupled substitution processes for trace element incorporation in sphalerite/wurtzite from Belgium and Germany. Meeting "Resources for Future Generations", Vancouver, Canada, 16.-21.06.2018, Abstracts, Vancouver.

Frenzel, M., Hirsch, T. \& Gutzmer, J. (2016): Gallium, germanium, indium, and other trace and minor elements in sphalerite as a function of deposit type - A meta-analysis. - Ore Geol. Rev., 76: 52-78; DOI: 10.1016/j.oregeorev.2015.12.017

Gäbler, H.-E., Melcher, F., Graupner, T., Bahr, A., Sitnikova, M.A., Henjes-Kunst, F., Oberthür, T., Brätz, H. \& Gerdes, A. (2011): Speeding up the analytical workflow for Coltan fingerprinting by an integrated mineral liberation analysis/LA-ICP-MS approach. - Geostand. Geoanalyt. Res., 35: 431-448; DOI: 10.1111/j.1751-908X.2011.00110.x

Geurts, G., Ommer, H. \& Stahl, H. (2004): Das Erbe des Erzes; Bd. 2: Die Gruben auf den Gangerzlagerstätten im Erzrevier Bensberg: 336 p.; Bergisch Gladbach (Förderverein des Bergischen Museums für Bergbau, Handwerk und Gewerbe).

Goffin, V., Evrard, M. \& Pirard, E. (2015): Critical metals in sphalerites from Belgian MVT deposits. - Proc. $13^{\text {th }}$ SGA Biennial Meeting, 24-27 August 2015, Nancy.

Goldmann, S., Junge, M., Wirth, R. \& Schreiber, A. (2018): Distribution of trace elements in sphalerite and arsenopyrite on the nanometre-scale - Discrete phases versus solid solution. - Eur. J. Mineral., 31: 325-333; DOI: 10.1127/ejm/2019/0031-2807

Henning, S., Werner, W. \& Graupner, T. (2018): Germanium, gallium and indium concentration and distribution in sulfides of hydrothermal veins from the Black Forest ore district. GeoBonn Conf., 2-6 September 2018, Abstracts: 189.

Henning, S., Graupner, T., Gäbler, H.-E., Goldmann, S., Kus, J. \& Krassmann, T. (2019): Germanium, gallium and indium distribution in base metal sulfides from hydrothermal veins of the Ruhr and Bergisches Land districts, Germany. $-15^{\text {th }}$ SGA Biennial Meeting, Glasgow, Abstracts.

Höll, R., Kling, M. \& Schroll, E. (2007): Metallogenesis of germanium -A review. - Ore Geol. Rev., 30:145-180; DOI: 10.1016/j. oregeorev.2005.07.034

Kelley, K.D., Leach, D.L., Johnson, C.A., Clark, J.L., Fayek, M., Slack, J.F., Anderson, V.M., Ayuso, R.A. \& Ridley, W.I. (2004): Textural, compositional, and sulfur isotope variations of sulfide minerals in the Red Dog Zn-Pb-Ag deposits, Brooks Range, Alaska: Implications for ore formation. - Econ. Geol., 99: 1509-1532; DOI: 10.2113/99.7.1509

Kwak, T.A.P. (2007): Fluid inclusions in skarns (carbonate replacement deposits). - J. Metamorph. Geol., 4: 363-384; DOI: 10.1111/j.1525-1314.1986.tb00358.x

Laznicka, P. (2010): Giant metallic deposits: Future sources of industrial metals: 732 p.; Berlin (Springer ).

Liu, Y., Hu, Z., Gao, S., Günther, D., Xu, J., Gao, C. \& Chen, H. (2008): In situ analysis of major and trace elements of anhy- 
drous minerals by LA-ICP-MS without applying an internal standard. - Chem. Geol., 257: 34-43; DOI: 10.1016/j. chemgeo.2008.08.004

Marscheider-Weidemann, F., Langkau, S., Hummen, T., Erdmann, L., Tercero Espinoza, L.A., Angerer, G., Marwede, M. \& Benecke, S. (2016): Rohstoffe für Zukunftstechnologien 2016: Auftragsstudie. Deutsche Rohstoffagentur (DERA) in der Bundesanstalt für Geowissenschaften und Rohstoffe, Berlin.

Mehner, W. (1993): Geschichte der Blei- und Kupfererzeugung am Unterharz: eine Chronik der Metallgewinnung von 1500-1992: 185 p.; Goslar (Harz-Metall-GmbH).

Melcher, F. \& Buchholz, P. (2013): Germanium. - In: Gunn, G. (ed.): Critical metals handbook: 177-203; Oxford (Wiley).

Melcher, F., Oberthür, T. \& Rammlmair, D. (2006): Geochemical and mineralogical distribution of germanium in the Khusib Springs $\mathrm{Cu}-\mathrm{Zn}-\mathrm{Pb}-\mathrm{Ag}$ sulfide deposit, Otavi Mountain Land, Namibia. - Ore Geol. Rev., 28 (1): 32-56.

Möller, P. (1987): Correlation of homogenization temperatures of accessory minerals from sphalerite-bearing deposits and $\mathrm{Ga} / \mathrm{Ge}$ model temperatures. - Chem. Geol., 61 (1/4): 153-159; DOI: 10.1016/0009-2541(87)90035-0

Möller, P. \& Dulski, P. (1993): Germanium and gallium distribution in sphalerite. - In: Möller, P. \& Lüders, V. (ed.): Formation of hydrothermal vein deposits. A case study of the $\mathrm{Pb}-\mathrm{Zn}$, barite and fluorite deposits of the Harz Mountains. - Monogr. Ser. Mineral Deposits, 30: 189-196.

Moskalyk, R.R. (2003): Gallium: The backbone of the electronics industry. - Minerals Eng., 16 (10): 921-929.

Nielsen, H. (1985): Sulfur isotope ratios in strata-bound mineralizations in Central Europe. - In: Gehlen, K. von (ed.): Stratabound sulfide ore deposits in Central Europe. - Geol. Jb., D 70: 225262.

Nikonow, W. \& Rammlmair, D. (2016): Risk and benefit of diffraction in energy dispersive X-ray fluorescence mapping. - Spectrochim. Acta, B 125: 120-126.

Nikonow, W. \& Rammlmair, D. (2017): Automated mineralogy based on energy dispersive X-ray fluorescence microscopy ( $\mu$-EDXRF) applied to plutonic rock thin sections in comparison to mineral liberation analyser. - Geosci. Instrum. Method. Data Syst., 6: 429-437; DOI: 10.5194/gi-2017-33

Onuk, P., Melcher, F., Mertz-Kraus, R., Gäbler, H.-E. \& Goldmann, S. (2017): Development of a matrix-matched sphalerite reference material (MUL-ZnS-1) for calibration of in situ trace element measurements by laser ablation-inductively coupled plasma-mass spectrometry. - Geostand. Geoanalyt. Res., 41: 263-272; DOI: 10.1111/ggr.12154

Paradis, S., Hannigan, P. \& Dewing, K. (2007): Mississippi ValleyType lead-zinc deposits (MVT). - In: Goodfellow, W.D. (ed.): Mineral deposits of Canada: A synthesis of major deposit-types, district metallogeny, the evolution of geological provinces, and exploration methods. - Geol. Assoc. Canada, Mineral Deposits Division, Spec. Publ., 5: 185-203.

Pfaff, K., Koenig, A., Wenzel, T., Ridley, I., Hildebrandt, L.H., Leach, D.L. \& Markl, G. (2011): Trace and minor element variations and sulfur isotopes in crystalline and colloform $\mathrm{ZnS}$ : Incorporation mechanisms and implications for their genesis. - Chem. Geol., 286 (3/4): 118-134; DOI: 10.1016/j. chemgeo.2011.04.018

Sahlström, F., Arribas, A., Dirks, P., Corral, I. \& Chang, Z. (2017): Mineralogical distribution of germanium, gallium and indium at the Mt Carlton High-Sulfidation Epithermal Deposit, NE Australia, and comparison with similar deposits worldwide. Minerals, 7 (11): 213; DOI: 10.3390/min 7110213
Saini-Eidukat, B., Melcher, F., Goettlicher, J. \& Steininger, R. (2016): Chemical environment of unusually Ge- and Pb-rich willemite, Tres Marias Mine, Mexico. - Minerals, 6 (1): 20; DOI: $10.3390 / \min 6010020$

Saxore (2015): Tellerhäuser Project Resource Statement by Simon Tear of H\&S Consultants, Brisbane, Australia.

Schirmer, T., Römer, F., Elwert, T. \& Goldmann, D. (2017): Characterization of tailings of the Rammelsberg ore deposit for a potential reprocessing. - Proc. European Metallurgical Conf. 2017, Leipzig.

Schwarz-Schampera, U. (2013): Indium. - In: Gunn, G. (ed.): Critical metals handbook: 204-229; Oxford (Wiley).

Schwarz-Schampera, U. \& Herzig, P.M. (2002): Indium: Geology, mineralogy, and economics: 257 p.; Berlin (Springer).

Schwerdtfeger, D. (2000): Untersuchungen zur karbonatgebundenen Zn-Pb-Mineralisation im Kalkwerk Hermsdorf, Erzgebirge. - Studienarbeit TU Bergakad. Freiberg: 39 p.

Seifert, T. \& Sandmann, D. (2006): Mineralogy and geochemistry of indium-bearing polymetallic vein-type deposits: Implications for host minerals from the Freiberg district, Eastern Erzgebirge, Germany. - Ore Geol. Rev., 28: 1-31; DOI: 10.1016/ j.oregeorev.2005.04.005

Stedingk, K. (2012): Geologie und Erzlagerstätten im Oberharz. Exk.-Fü. Veröff. Dt. Ges. Geowiss., 247: 9-81.

Taylor, S.R. \& McLennan, S.M. (1985): The continental crust: Its composition and evolution: 312 p.; Oxford (Blackwell).

Timofeev, A. \& Williams-Jones, A.E. (2014): Controls on the distribution of gallium in the Nechalacho REE deposit, NWT, Canada. - Econ. Geol., 110 (1): 173-185; DOI: 10.2113/econgeo.110.1.173

Werner, W. \& Dennert, V. (2004): Lagerstätten und Bergbau im Schwarzwald: Ein Führer unter besonderer Berücksichtigung der für die Öffentlichkeit zugänglichen Bergwerke: 334 p.; Freiburg i. Br. (Landesamt für Geologie, Rohstoffe und Bergbau Baden-Württemberg).

Werner, W., Franzke, H.J., Wirsing, G., Jochum, J., Lüders, V. \& Wittenbrink, J., mit einem Beitrag von B. Steiber (2002): Die Erzlagerstätte Schauinsland bei Freiburg im Breisgau. Bergbau, Geologie, Hydrogeologie, Mineralogie, Geochemie, Tektonik und Lagerstättenentstehung. - Ber. Naturforsch. Ges. Freiburg i. Br., 92 (1): 113 p.

Wilson, S.A., Ridley, W.I. \& Koenig, A.E. (2002): Development of sulfide calibration standards for the laser ablation inductivelycoupled plasma mass spectrometry technique. - J. Anal. At. Spectrom., 17: 406-409; DOI: 10.1039/b108787h

Ye, L., Cook, N., Ciobanu, C., Yuping, L., Qian, Z., Tiegeng, L., Wei, G., Yulong, Y. \& Danyushevsky, L. (2011): Trace and minor elements in sphalerite from base metal deposits in South China: A LA-ICPMS study. - Ore Geol. Rev., 39: 188-217; DOI: 10.1016/j.oregeorev.2011.03.001

Yuan, J.-H., Zhan, X.-C., Fan, C.-Z., Zhao, L.-H., Sun, D.-Y., Jia, Z.-R., Hu, M.-Y. \& Kuai, L.-J. (2012): Quantitative analysis of sulfide minerals by laser ablation-inductively coupled plasmamass spectrometry using glass reference materials with matrix normalization plus sulfur internal standardization calibration. - Chinese J. Anal. Chem., 40: 201-207; DOI: 10.1016/s18722040(11)60528-8

Manuscript received: 20.06.2019

Revisions required: 01.08.2019

Revised version received: 16.08 .2019

Accepted for publication: 19.08.2019 